\title{
The first Italian blast-induced liquefaction test (Mirabello, Emilia-Romagna, Italy): description of the experiment and preliminary results
}

Sara Amoroso ${ }^{1, *}$, Giuliano Milana ${ }^{1}$, Kyle M. Rollins ${ }^{3}$, Cesare Comina ${ }^{4}$, Luca Minarelli ${ }^{5}$, Maria R. Manuel ${ }^{6}$, Paola Monaco ${ }^{7}$, Marco Franceschini $^{8}$, Marco Anzidei ${ }^{2}$, Cameron Lusvardi ${ }^{3}$, Luciana Cantore $^{1}$, Andrea Carpena ${ }^{9}$, Stefano Casadei ${ }^{10}$, Francesca R. Cinti ${ }^{2}$, Riccardo Civico ${ }^{2}$, Brady R. Cox ${ }^{11}$, Paolo Marco De Martini ${ }^{2}$, Giuseppe Di Giulio ${ }^{1}$, Deborah Di Naccio ${ }^{1}$, Giuseppe Di Stefano ${ }^{2}$, Johann Facciorusso ${ }^{12}$, Daniela Famiani ${ }^{2}$, Federico Fiorelli ${ }^{8}$, Daniela Fontana ${ }^{13}$, Sebastiano Foti ${ }^{14}$, Claudia Madiai ${ }^{12}$, Valeria Marangoni ${ }^{4}$, Diego Marchetti ${ }^{15}$, Silvano L. Marchetti ${ }^{15}$, Luca Martelli ${ }^{16}$, Mauro Mariotti ${ }^{17}$, Elena Muscolino ${ }^{8}$, Davide Pancaldi ${ }^{8}$, Daniela Pantosti ${ }^{2}$, Federico Passeri ${ }^{14}$, Arianna Pesci ${ }^{18}$, Giovanni Romeo ${ }^{2}$, Vincenzo Sapia ${ }^{2}$, Alessandra Smedile ${ }^{2}$, Marco Stefani ${ }^{19}$, Gabriele Tarabusi ${ }^{18}$, Giordano Teza ${ }^{20}$, Maurizio Vassallo ${ }^{1}$, Fabio Villani ${ }^{1}$

${ }^{1}$ Istituto Nazionale di Geofisica e Vulcanologia, L'Aquila, Italy

${ }^{2}$ Istituto Nazionale di Geofisica e Vulcanologia, Rome, Italy

${ }^{3}$ Brigham Young University, Provo, Utah, USA

${ }^{4}$ University of Turin, Turin, Italy

5 Geotema srl, University of Ferrara spin-off company, Ferrara, Italy

${ }^{6}$ GEO Geotecnica e Geognostica srl, Arpino, Italy

${ }^{7}$ University of L'Aquila, L'Aquila, Italy

${ }^{8}$ Teleios srl, Castel Maggiore, Italy

${ }^{9}$ Georeflex srl, Piacenza, Italy

${ }^{10}$ INDGEO due srl fondazioni speciali, San Giuseppe di Comacchio, Italy
11 The University of Texas at Austin, Austin, Texas, USA

12 University of Florence, Florence, Italy

13 University of Modena and Reggio Emilia, Modena, Italy

${ }^{14}$ Politecnico di Torino, Turin, Italy

15 Studio Prof. Marchetti srl, Rome, Italy

${ }^{16}$ Emilia-Romagna Region, Bologne, Italy

17 Sara Electronic Instruments srl, Perugia, Italy

${ }^{18}$ Istituto Nazionale di Geofisica e Vulcanologia, Bologne, Italy

19 University of Ferrara, Ferrara, Italy

${ }^{20}$ University of Padua, Padua, Italy

\section{Article history}

Received March 19, 2017; accepted July 2, 2017.

Subject classification:

Liquefaction, Blast test, Geotechnical and geophysical surveys, Emilia-Romagna earthquake, Seismic design.

\section{ABSTRACT}

Soil liquefaction can result in significant settlement and reduction of load-bearing capacity. Moreover, the generation of pore pressure during an earthquake and its post-seismic dissipation can generate permanent deformations and settlements. The quantitative evaluation of post-liquefaction settlements is of extreme importance for engineering purposes, i.e. for earthquake-resistant design of new buildings and safety evaluation of existing ones. Quantifying the extent of these phenomena is, however, rather difficult. Uncertainties arise from the stochastic nature of the earthquake loading, from the simplifications of soil models, and from the difficulty in establishing correlations between the pre-earthquake soil state and the post-seismic deformations.
Field scale liquefaction tests, under controlled conditions, are therefore important for a correct quantification of these phenomena. Recent experiences (e.g. New Zealand, United States) show that liquefaction can be induced and monitored with field scale blast tests to study the related effects on soil geotechnical properties. Within this framework this paper introduces the preliminary results obtained from a research project on blast-induced liquefaction at field scale. Tests were performed at a trial site located in Mirabello (Ferrara, Italy), a village strongly affected by liquefaction phenomena during the 2012 Emilia Romagna earthquake. Invasive tests, such as piezocone, seismic dilatometer and down-hole tests, and non-invasive tests were carried out before and after the execution of two blast test sequences to study the 
variation in physical properties of the soils. Pore pressure transducers, settlement profilometers and accelerometers were installed with the objective of measuring, during and after the detonations, the generation and subsequent dissipation of the pore pressure, the vertical deformations, and the blast-induced ground motions respectively. Variations in load distribution on deep foundations due to soil liquefaction were also evaluated on a test micropile instrumented with a strain gauge array. Topographical surveys were carried out to measure ground surface settlements. Laboratory tests and trenches also provided increased understanding of the site characteristics.

\section{Introduction}

The occurrence of liquefaction can result in significant settlement and reduction of load-bearing capacity. In particular, the dissipation of earthquake-induced pore pressure can initiate liquefaction-induced settlements, frequently causing damage to foundations and lifelines [Kramer 1996]. According to the Eurocode 8 [EN 19985 2004], the quantitative evaluation of post-liquefaction settlements is of extreme importance for engineering purposes, i.e. for earthquake-resistant design of new buildings and safety evaluation of existing ones. In this respect, different procedures for the deformation assessment were developed using ground response analyses [Pyke et al. 1975], or simplified procedures [Tokimatsu and Seed 1987, Ishihara and Yoshimine 1992]. Most of the currently published methods make use of in situ geotechnical investigations [Tokimatsu and Seed 1987, Ishihara and Yoshimine 1992, Idriss and Boulanger 2008, Zhang et al. 2002]. Either the standard penetration test or the cone penetration test is used in this respect. Few published papers calculate the liquefaction-induced settlement based on the shear wave velocity [Yi 2010], that can be measured by geophysical surveys or seismic geotechnical in situ tests, such as the seismic dilatometer test. However, quantifying the extent of these phenomena is rather difficult, due to the stochastic nature of the earthquake loading, the simplifications of soil models and the difficulty of developing reliable correlations between the actual soil state and the post-seismic deformations [Györi et al. 2011].

For the above reasons, the blast technique has been developed based on the controlled detonation of explosives to generate long duration cyclic shaking of the ground and thereby to test the in situ soil liquefaction potential, as shown by recent experiences in New Zealand and United States [e.g. Wentz et al. 2015, Finno et al. 2016]. Blast tests produce accelerations at high frequency, much higher than that of real earthquakes, but ground velocity and displacement amplitudes are similar to those generated by a strong earthquake. Sequential blasts can also induce multiple shear strain cycles and generate excess pore pressure build-up. In situ geotechnical monitoring, laboratory investigations and geophysical surveys are usually coupled with the detonations to optimize their effectiveness [Ashford et al. 2004, Rollins et al. 2004, Gohl et al. 2001] and to evaluate soil parameters variations before and after liquefaction.

The present work shows the activities performed for a blast experiment at a target site in northern Italy. This paper introduces the preliminary results in the framework of a research project on induced liquefaction, performed at a trial site located in Mirabello (Ferrara, Italy), a village strongly affected by liquefaction phenomena during the 2012 Emilia Romagna earthquake [Caputo and Papathanasiou 2012, Emergeo Working Group 2013, Fioravante et al. 2013, Vannucchi et al. 2012, Facciorusso et al. 2016]. At the Mirabello site, an intensive geological, geotechnical and geophysical campaign was carried out before and after the execution of two blast test sequences. Pore pressure transducers and settlement profilometers were installed with the purpose of measuring, during and after the blast test, the generation and subsequent dissipation of the pore water pressure along with the vertical deformations, respectively. Detailed topographical surveys were also performed to monitor vertical deformations of the ground surface.

\section{Selection of the test site}

The selection of an experimental site where liquefaction effects are well documented was chosen as a reliable criteria to test the technique and to check its results. In this respect the 2012 Emilia seismic sequence $\left(M_{L} 5.9\right.$ and $M_{L} 5.8$ on May 20 and 29, 2012, respectively) produced significant and widespread liquefaction effects in various areas of the Emilia-Romagna Region (Figure 1a), as observed during extensive field reconnaissance by INGV-Emergeo [Emergeo Working Group 2013], University of Ferrara [Caputo and Papathanasiou 2012] and Emilia-Romagna Region [Regione Emilia-Romagna 2012]. The most significant and widespread liquefaction phenomena occurred in the villages of San Carlo and Mirabello (Ferrara, Italy). Mirabello was therefore chosen to carry out the blast test trial.

The selection of the site was then guided by the necessity to limit the level of vibrations generated by the detonation to an acceptable threshold that is strictly related to human perception and to the presence of buildings. Following previous blast liquefaction experiences [e.g. Kato et al. 2015, Ashford et al. 2004, Rollins et al. 2004] the peak particle velocity (PPV) is a parameter connected with the human perception and building 

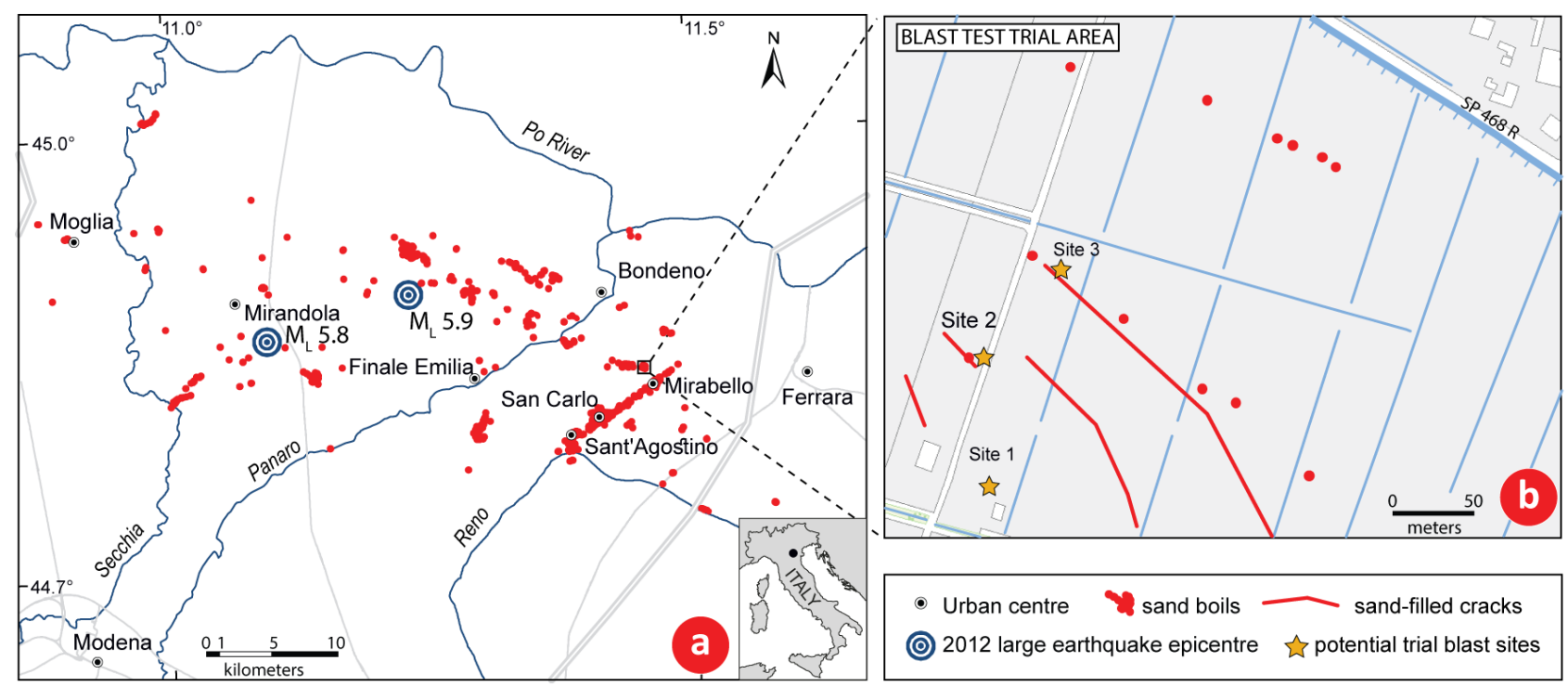

Figure 1. (a) Map showing surface manifestations of liquefaction following 2012 Emilia earthquake (data from Emergeo Working Group [2013], Caputo and Papathanasiou [2012] and Regione Emilia-Romagna [2012]); (b) map of the potential trial blast sites in Mirabello village.

damage. $P P V$, expressed in $\mathrm{m} / \mathrm{s}$, can be estimated as:

$$
\begin{aligned}
& P P V=1.47\left(\frac{R}{\sqrt{W}}\right)^{-1.325} \\
& P P V=3.21\left(\frac{R}{\sqrt{W}}\right)^{-1.325}
\end{aligned}
$$

where $R$ is the distance ( $\mathrm{m}$ ) from the center of a blast area and $W$ is the weight $(\mathrm{kg})$ of the individual charges. Equation (1) indicates the mean PPV and Equation (2) refers to the upper bound $P P V$ according to Kato et al. [2015]. On average $P P V$ values $<1.5-3.0 \mathrm{~mm} / \mathrm{s}$ may be barely perceptible to humans, while $P P V$ values $<$ 3.0-5.0 $\mathrm{mm} / \mathrm{s}$ prevent historic and residential buildings from damage. With reference to the aim of providing a first order of magnitude estimation for the Mirabello blast experiment, given a charge weight of $4 \mathrm{~kg}$, a safety distance of $350 \mathrm{~m}$ would generate a PPV between 1.5 and $3.0 \mathrm{~mm} / \mathrm{s}$ which is an acceptable value for human perception and damage to building.

The above considerations made it desirable to locate the blast test site $1.5 \mathrm{~km}$ from the center of Mirabello village, where liquefaction phenomena had been detected, but relatively few buildings (sometimes ruins) are present and were at least $350 \mathrm{~m}$ from the trial area. Preliminarily, three potential sites were selected in a narrow area (Figure 1b). After the 2012 Emilia seismic sequence widespread liquefaction was observed at Site 2 and Site 3, but no evidence of sand boils was detected at Site 1. In detail, Site 2 was situated on one large linear liquefaction feature from the 2012 earthquake about 33 to $36 \mathrm{~m}$ long, consisting of multiple sand volcanoes, about 3 to $8 \mathrm{~m}$ wide.
The stratigraphical succession of the selected area consists of Holocene and late Pleistocene sediments, accumulated in alluvial plain environments [Regione Emilia-Romagna 2013], as schematically shown in Figure 2. The proposed chrono-stratigraphical scheme (Figure 2) was obtained using stratigraphical correlations based on radiocarbon datings [Amorosi et al. 2016, Bruno et al. 2016]. Moving downward from the ground surface, the Ravenna Subsynthem (AES8) can be schematically described: the surface is usually composed of reworked soils and/or fine sediments that possibly incorporate extruded liquefied sand; then fine-grained sediments, deposited in an interfluvial depression, are encountered; below this, fluvial silty-sand and sandysilt sediments of heterogeneous Apenninic provenance, deposited in crevasse splays in pre-Roman times, are located; silty sands of the Po River channel are then detected. Finally, the Villa Verrucchio Subsynthem (AES7) is encountered through the Syn-Glacial Po River braided deposits composed of silty sands, even coarse sands. Additional details regarding the stratigraphical units can be found in Minarelli et al. [2016].

On January 2016 in each of the three sites, 20 m-deep piezocone tests (Site1-CPTu1, Site2-CPTu2, Site3-CPTu3) were performed in order to provide a first-order liquefaction assessment according to the "simplified procedure". The CPT-based liquefaction analyses were carried out using the method proposed by Idriss and Boulanger [2008], assuming the seismic input (moment magnitude $M_{w}=6.1$, peak ground acceleration $P G A=0.2175 \mathrm{~g}$ ) obtained from the seismic microzonation study of the Mirabello municipality [Regione Emilia-Romagna 2013, Geotema 2014]. The 


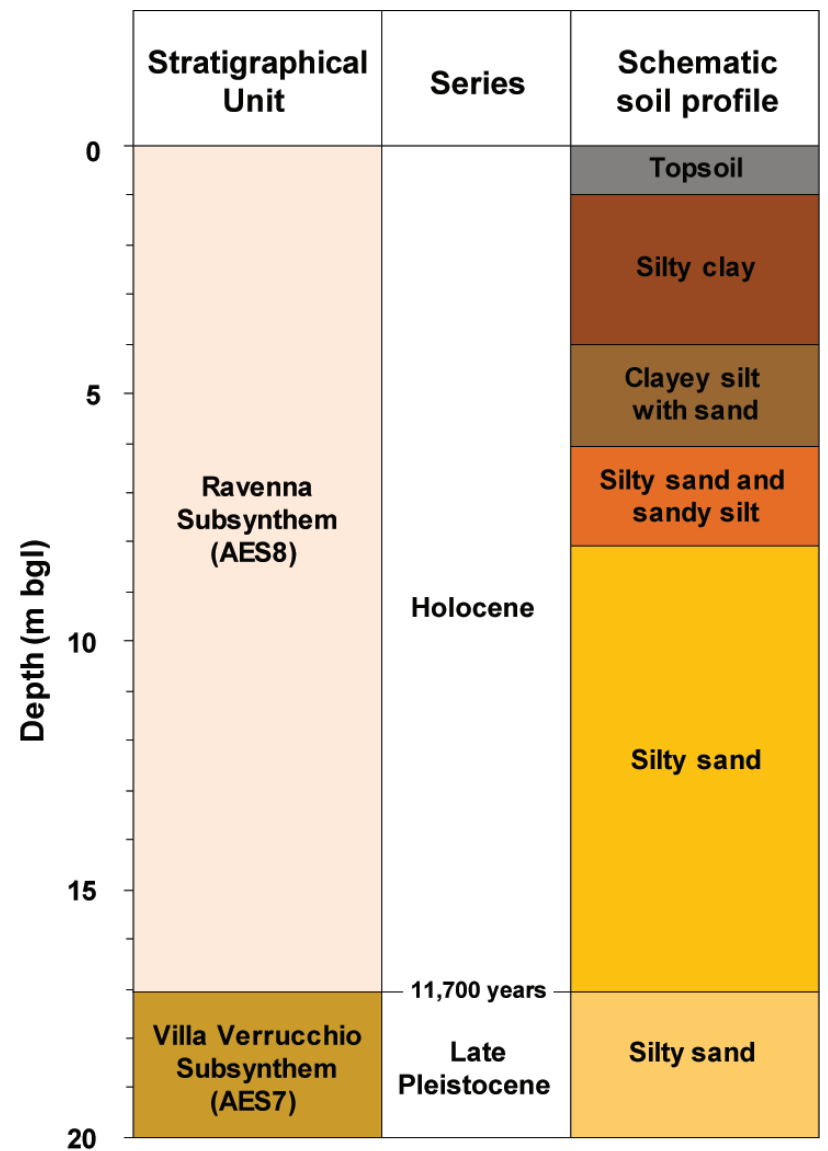

Figure 2. Mirabello trial site: stratigraphical profile and schematic soil profile.

ground water table (GWT) was preliminarily assumed equal to the in situ GWT, as provided by the piezocone tests. The estimation of the liquefaction potential index according to Iwasaki et al. [1982] provided low liquefaction risk (almost zero) at Site 1 and from low to high risk at Site 2 and Site 3, confirming the observations from the 2012 earthquake. As a consequence, Site 1 was directly excluded for the blast experiment.

The selection of Site 2 was supported by the greater thickness of the main potential liquefiable layer (i.e. fluvial Apenninic deposits) that corresponds to $2 \mathrm{~m}$ (from 6 to $8 \mathrm{~m} \mathrm{bgl}$ ) at Site 2 and to $1 \mathrm{~m}$ (from 7 to $8 \mathrm{~m} \mathrm{bgl})$ at Site 3 .

\section{Design of the blast test}

3.1 Pre-blast site investigation and liquefaction assessment Soon after the selection of Site 2, in January and February 2016 a preliminary geological, geotechnical and geophysical characterization was carried out in proximity to the observed liquefaction evidence. The aim of the surveys was to characterize the subsoil model at Site 2, and consequently to set-up the blast layout (blue symbols and lines in Figures $3 \mathrm{a}$ and $3 \mathrm{~b})$. Besides the piezocone test (CPTu2), the in situ in- vestigations (Figure 3b) consisted of: one $20 \mathrm{~m}$-deep borehole ( $\mathrm{S} 1$ ), four standard penetration tests within S1, one 19 m-deep seismic dilatometer test (SDMT1), and one $15 \mathrm{~m}$-deep dynamic probe super heavy test (DPSH1). The GWT in the borehole was located at $4.2 \mathrm{~m}$ bgl, confirming the CPTu evaluation. Nineteen disturbed samples were retrieved with coring and a SPT (Standard Penetration Test) split barrel sampler to perform sieve analyses and Atterberg limits, while five disturbed samples on sandy deposits and one disturbed sample on a peaty layer were retrieved with coring to execute compositional analyses and radiocarbon dating, respectively. Moreover, four undisturbed samples were also retrieved with a Shelby sampler to perform dynamic and cyclic laboratory tests, that are still ongoing. Geophysical tests (Figures 3a, 3b) included: two down-hole tests (DH1) within S1 borehole, one by means of a vertical seismic array of 8 triaxial (10 $\mathrm{Hz}$ ) geophones at $1 \mathrm{~m}$ spacing, and one with a pair of triaxial geophone $(10 \mathrm{~Hz})$, three MASW (Multichannel Analysis of Surface Waves) using an array of 72 (MASW1, MASW2) or 48 (MASW3) vertical $(4.5 \mathrm{~Hz})$ geophones at $1 \mathrm{~m}$ spacing, two P-wave and two S-wave tomographies along MASW1 and MASW2 profiles, seven $2 \mathrm{D}$ electrical resistivity tomographies via 64 electrodes at $2 \mathrm{~m}$ spacing (ERT1, ERT2, ERT3, ERT4) or 72 electrodes at $1 \mathrm{~m}$ spacing (ERT5, ERT6, ERT 7), and one small (SM) and one big (BM) passive $2 \mathrm{D}$ array consisting both of twelve seismic stations (equipped with three-components Lennartz-5s velocimeter) in a spiral-shape configuration.

The combination of the abovementioned investigations provided a preliminary geotechnical model (Figure 4) for the liquefaction assessment at the Mirabello trial site. The units are listed below including the Unified Soil Classification System (USCS) descriptors according to ASTM D2487-11 [2011]:

- Topsoil from 0 to $1 \mathrm{~m}$ bgl (USCS descriptor: $\mathrm{CH}$ );

- Silty clay from 1 to $4 \mathrm{~m}$ bgl (USCS descriptor: $\mathrm{CH}$ ); Clayey silt with sand from 4 to $6 \mathrm{~m} \mathrm{bgl}$ (USCS descriptor: CL-CH);

- Silty sand and sandy silt (fluvial Apenninic deposits) from 6 to $8 \mathrm{~m}$ bgl (USCS descriptor: ML-SM);

- Silty sand (paleochannel of the Po River) from 8 to $17 \mathrm{~m}$ bgl (USCS descriptor: SM);

- Silty sand (Syn-Glacial braided Po River deposits) from 17 to $20 \mathrm{~m} \mathrm{bgl} \mathrm{(USCS} \mathrm{descriptor:} \mathrm{SM).}$

Table 1 illustrates the geotechnical parameters estimated for the model: corrected cone tip penetration resistance before blast test $\left(q_{t}\right)$ from CPTu test (see also Figure 4$)$, horizontal stress index $\left(K_{D}\right)$ from 


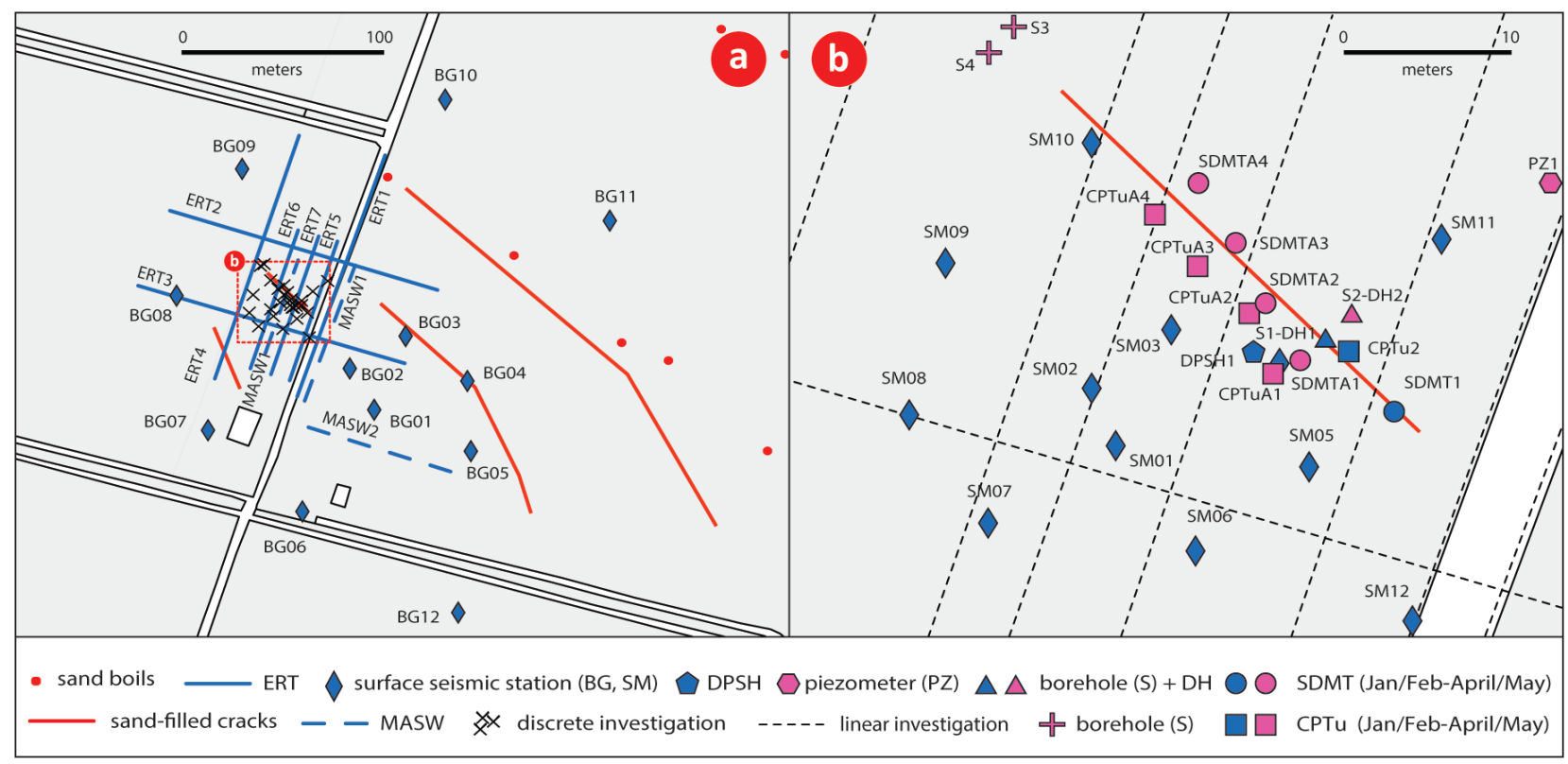

Figure 3. Map of pre-blast investigations at the trial Mirabello blast test site: blue color is related to the January/February site campaign, and pink color indicates the April/May investigations. (a) General map; (b) detailed map.

SDMT test, shear wave velocity $\left(V_{s}\right)$ from SDMT and $\mathrm{DH}$ tests and fine content $(F C)$ from sieve analyses. $F C$ is much higher than in previous blast tests [Ashford et al. 2004].

Therefore, the preliminary CPT-based liquefaction analyses were supplemented by additional analyses based on SDMT and DH data according to the "simplified procedure", assuming the same seismic input already used for CPTu liquefaction assessment.

The liquefaction analyses based on the flat dilatometer test (DMT) were carried out using Monaco et al. [2005], Tsai et al. [2009] and Robertson [2012] formulations, while the analyses based on the shear wave velocity $V_{s}$ were carried out according to the methods proposed by Andrus and Stokoe [2000] and Kayen et al. [2013]. The GWT was assumed equal to $4.2 \mathrm{~m}$ bgl. CPTu, DMT and $V_{s}$ data found approximately the same potential liquefiable layers: the upper one, that is the main one, was detected between 6 and $8 \mathrm{~m}$ bgl corresponding to the fluvial Apenninic deposits (liquefaction safety factor $F s \approx 0.6-0.8$ ), and the lower one, that is less liquefiable, between 8 and $13 \mathrm{~m}$ bgl into the upper paleochannel of the Po River (Fs $\approx 0.9-1.2$ ).

Compositional analyses of sands in the pre-blast conditions were performed on the $0.125-0.250 \mathrm{~mm}$ fraction, according to the Gazzi-Dickinson method, in order to reduce the effect of grain size over composition [Lugli et al. 2007, Weltje 2002]. The examined sands are characterized by well-defined fields and show a clear trend from lithoarenitic to quartz-feldspar-rich compositions, similar to that evidenced by Fontana et al. [2015].

\section{More specifically:}

- sands from the CL-CH deposits (4-6 m bgl) represent a very subordinate fraction. They are the most lithoarenitic, with shales as the dominant lithic type. Quartz plus feldspars range from $52.9 \%$ to $58.0 \%$ of the whole sandy fraction. Siliciclastic fine-grained lithics (shale, siltstones, low-grade metamorphites)

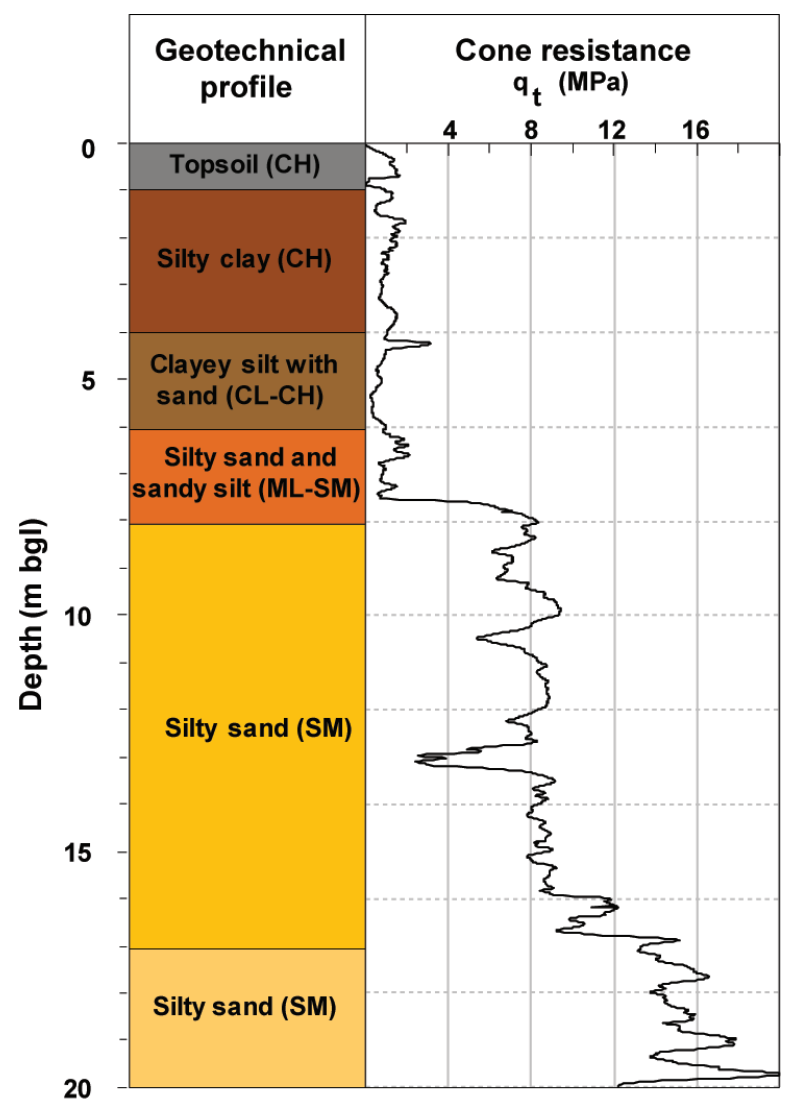

Figure 4. Mirabello trial site: geotechnical profile and representative corrected cone tip resistance $\left(q_{t}\right)$ profile. 


\begin{tabular}{lcccc}
\hline depth (m) & $\begin{array}{c}\mathbf{q}_{\mathbf{t}} \\
(\mathbf{M P a})\end{array}$ & $\begin{array}{c}\mathbf{K}_{\mathrm{D}} \\
(-)\end{array}$ & $\begin{array}{c}\mathbf{V}_{\mathbf{S}} \\
(\mathbf{m} / \mathbf{s})\end{array}$ & $\begin{array}{c}\mathbf{F C} \\
(\mathbf{\%})\end{array}$ \\
\hline $0-1$ & $0.5-1.5$ & $20.0-45.0$ & $85-105$ & - \\
$1-4$ & $0.8-1.8$ & $4.5-17.5$ & $135-160$ & 100 \\
$4-6$ & $0.3-1.1$ & $3.0-4.0$ & $140-170$ & $70-80$ \\
$6-8$ & $0.8-2.0$ & $1.5-3.0$ & $155-170$ & $25-75$ \\
$8-17$ & $6.0-11.5$ & $3.0-6.0$ & $170-215$ & $20-35$ \\
$17-20$ & $13.0-18.0$ & $3.5-6.0$ & $200-225$ & $25-30$ \\
\hline
\end{tabular}

Table 1. Values of the corrected cone tip penetration resistance before blast test $\left(q_{t}\right)$, horizontal stress index $\left(K_{D}\right)$, shear wave velocity $\left(V_{S}\right)$ and fine content $(F C)$ for the preliminary geotechnical model at Mirabello trial site.

vary from $19.0 \%$ to $24.0 \%$ and carbonate lithics (sparitic and micritic limestones, calcite spars) range from $13.8 \%$ to $14.4 \%$. Micas, glauconitic grains, heavy minerals and Fe-oxides are subordinate components;

- sands from the ML-SM deposits (6-8 $\mathrm{m} \mathrm{bgl}$ ) show a composition similar to the upper layer, but are slightly enriched in quartz and feldspars (up to 63.0 $\%)$ and reduced in siliciclastic lithic fragments (13.719.4\%);

- sands from the upper SM deposits (8-17 m bgl) clearly differ in composition and show a higher quartz-feldspar content. In detail this layer has quartz and feldspars from $69.7 \%$ to $74.7 \%$, siliciclastic fine-grained lithics from $8.3 \%$ to $11.6 \%$ and carbonate lithics from $9.9 \%$ to $14.1 \%$;

- compositional field of the deepest sands that belong to the lower SM deposits (17-20 m bgl) overlaps the upper SM sands, but with higher amounts of quartz (single crystal) and lower of shales.

The shifting composition at $8 \mathrm{~m}$ depth is interpreted as the transition from the Apenninic to the Alpine provenance of the deeper Po river sands.

3.2 Blast test layout, site investigation and monitoring instrumentation

Based on the soil profile and liquefaction assessment, the blast layout was designed in February and March 2016.

Two sequences of blast charges were planned to detonate separately. For the first blast eight blast holes (BH) were equally distributed around a 5 m-radius ring at $45^{\circ}$, and an offset of $22.5^{\circ}$ for the second blast holes was adopted (Figure $5 \mathrm{~b}$ ). In each blast hole $1.875 \mathrm{~kg}$ and $2.5 \mathrm{~kg}$ charges were located in the potential liquefiable layers at $7.0 \mathrm{~m} \mathrm{bgl}$ (fluvial Apenninic deposits) and $11 \mathrm{~m} \mathrm{bgl}$ (upper paleochannel of the Po River) depths, respectively. The two charges in the same hole were planned to detonate almost simultaneously (delay of detonation $42 \mathrm{~ms}$ ), while the delay of detonation between each of the eight holes was fixed at $200 \mathrm{~ms}$. This blasting plan provided an acceptable level of vibration for human perception and damage to building since the charge $W=4.375 \mathrm{~kg}$ and the distance $R=350 \mathrm{~m}$ predict a $P P V \approx 1.66-3.63 \mathrm{~mm} / \mathrm{s}$.

In order to evaluate ground behavior over the likely area of influence for the blasts, four additional companion soundings consisting of a $15 \mathrm{~m}$-deep piezocone and a seismic dilatometer (CPTUA1-SDMTA1, CPTuA2-SDMTA2, CPTuA3-SDMTA3, CPTuA4-SDMTA4) were performed along the line of sand boils observed in the 2012 earthquake from the center of the blast ring to a $12 \mathrm{~m}$-radial distance (Figure $3 \mathrm{~b}$ ). Three supplementary boreholes (S2, S3, S4) and one piezometer (PZ1) were also performed in order to retrieve additional disturbed and undisturbed samples in the silty sands and sandy silt of the fluvial Apenninic deposits and of the paleochannels of the Po Rivers, to carry out one extra $20 \mathrm{~m}$-deep down-hole $V_{s}$ test (DH2), and to monitor the ground water table (pink symbols in Figures $3 \mathrm{a}$ and $3 \mathrm{~b}$ ).

Four "Sondex" settlement profilometers (MPA1, MPA2, MPA3, MPA4) were located in correspondence with the four CPTu-SDMT pairs to monitor the vertical settlements as a function of depth soon after each blast sequence. The reference base was anchored at $18 \mathrm{~m}$ which corresponds with the stiffest and deepest silty sandy layer of the paleochannel of the Po River. Elevation measurements were also made with a level at five points (MLA, Figure 5b) within the blast zone to record the vertical ground surface settlements over time after the blast. Moreover, thirty-one survey stakes (ML, Figure 5b) were placed along a line out from the center of the blast zone to record the total vertical settlements due to each blast using a survey level. These discrete point measurements were also coupled with detailed topographical surveys, by means of Terrestrial Laser Scanning (TLS), that allows an accurate and cost-effective representation of the topographical details of the observed surface, and Structure from Motion (SfM) aerial photogrammetry, that gives a highly automated registration of the images in the same reference frame by means of efficient feature-based or area-based matching techniques. The combinations of these topographical surveys provided very accurate and realistic 3D digital models of the investigated area (approximately a 20 $\mathrm{m}$-diameter circle from the center of the blast zone), useful to monitor surface deformation via repeated surveys before and soon after each detonation.

The blast instrumentation layout also included a 


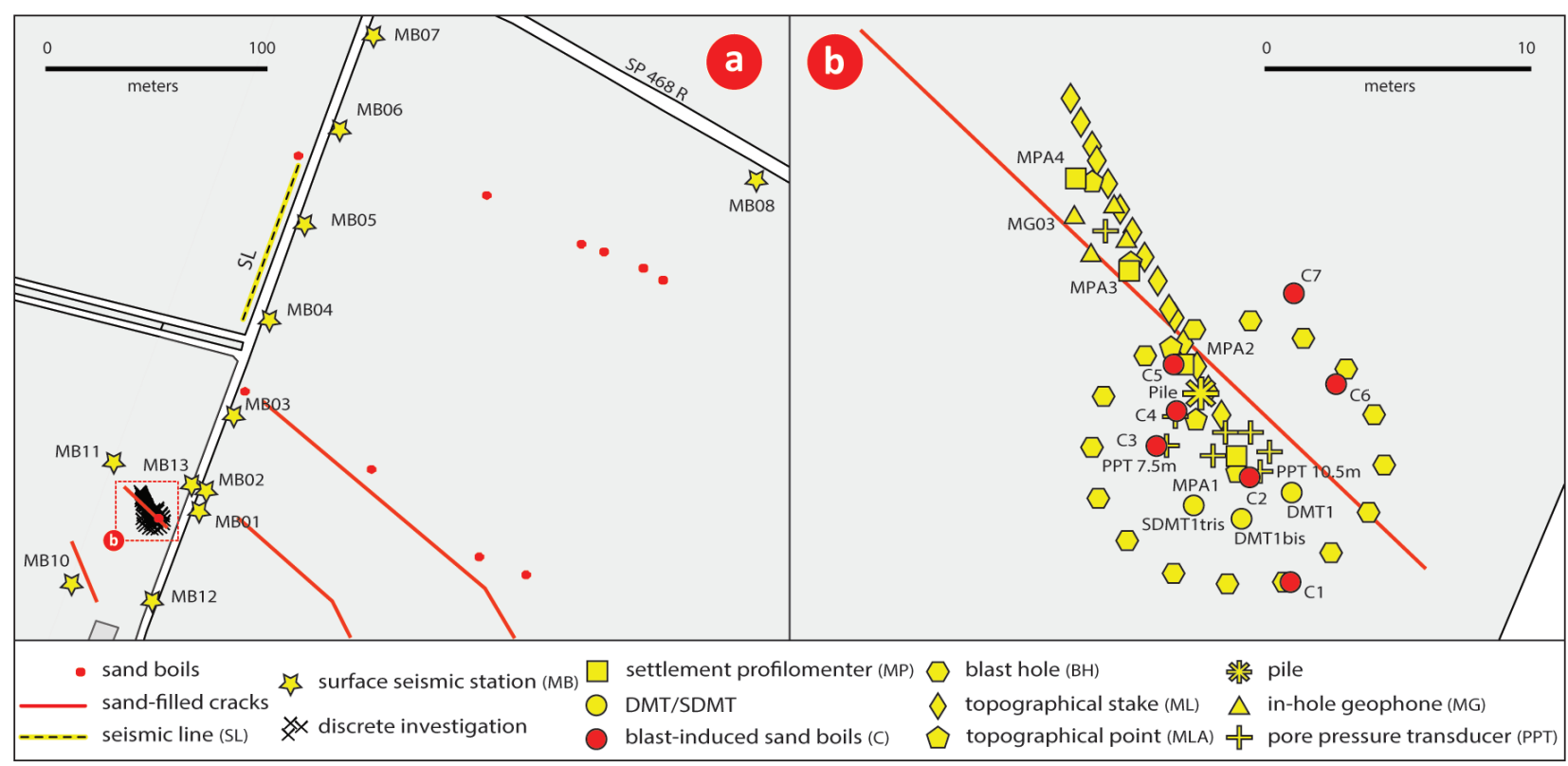

Figure 5. Map of blast investigations at the trial Mirabello blast test site. (a) General map; (b) detailed map.

down-hole 3D $(10 \mathrm{~Hz})$ geophone array set up to record the blast signal. The array consisted of eight sensors (MG, Figure $5 \mathrm{~b}$ ) at each corner of a cube with side dimensions of about $1.5 \mathrm{~m}$. The top four sensors were located near the top of the main liquefiable layer $(6.3 \mathrm{~m} \mathrm{bgl})$ and the bottom four sensors near the bottom of the same layer $(7.8 \mathrm{~m} \mathrm{bgl})$. The center of the array was situated $10 \mathrm{~m}$ from the center of the blast ring, estimating that at this distance the geophones would not saturate during the detonations. Additionally, thirteen surface seismic stations (MB, Figure 5a) equipped with a 24bit digitizer (reftek) coupled to a velocimeter (Lennartz-5s) and an accelerometer (Episensor-1s), were placed between 20 and $320 \mathrm{~m}$ from the blast center, to acquire the ground motion for each blast pulse. A linear array of 48 vertical $(4.5 \mathrm{~Hz})$ geophones at $1.5 \mathrm{~m}$ spacing (SL, Figure 5a) was also located on the surface about $150 \mathrm{~m}$ away from the blast center.

The installation of an instrumented micropile was additionally included in the blast test experiment (Figure 6) in order to improve the knowledge on the design of deep foundations in case of liquefaction.

The $250 \mathrm{~mm}$ diameter concrete micropile was reinforced internally with a $114 \mathrm{~mm}$-diameter steel pipe with a $10 \mathrm{~mm}$-wall thickness and its center was located $2.7 \mathrm{~m}$ from the center of the blast zone (Figure $5 \mathrm{~b}$ ). Based on the CPTu2 data the micropile was designed to reach the upper paleochannel of the Po River at a depth of $17 \mathrm{~m}$ using overburden drilling. Strain gauges were installed at approximately $1.5 \mathrm{~m}$ depth intervals along the pile length to a depth of about $0.3 \mathrm{~m}$ above the bottom of the pile in order to measure the strain, and consequently calculate the load in the pile during the two blast sequences. In addition, dynamic CASE load tests [Goble et al. 1967] were considered suitable to be performed on the pile to evaluate the load-settlement curve and the distribution of shaft and base resistances of the pile before and after the detonations. Pile capacity estimates based on the CPTu2 data supported the evaluation of a $700 \mathrm{~kg}$-weight falling through different distances $(20 \mathrm{~cm}, 50 \mathrm{~cm}$ and $70 \mathrm{~cm})$ to perform each CASE test.

Eight pore pressure transducers (PPT, Figure $5 \mathrm{~b}$ ) were located in the blast zone to monitor the generation and dissipation of excess pore pressure during the blasts. In particular, five piezometers were installed in the silty sandy layers at depths between 6 and $11 \mathrm{~m} \mathrm{bgl}$, typically about $1 \mathrm{~m}$ from the center of the blast ring where the effect of the blast-induced pore pressure generation was expected to be maximum. Two addi-

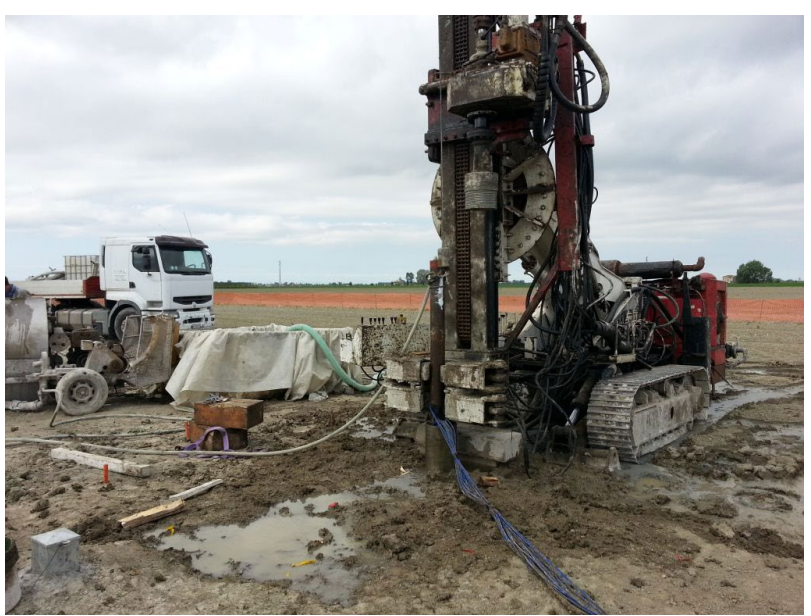

Figure 6. Installation of the instrumented micropile. 


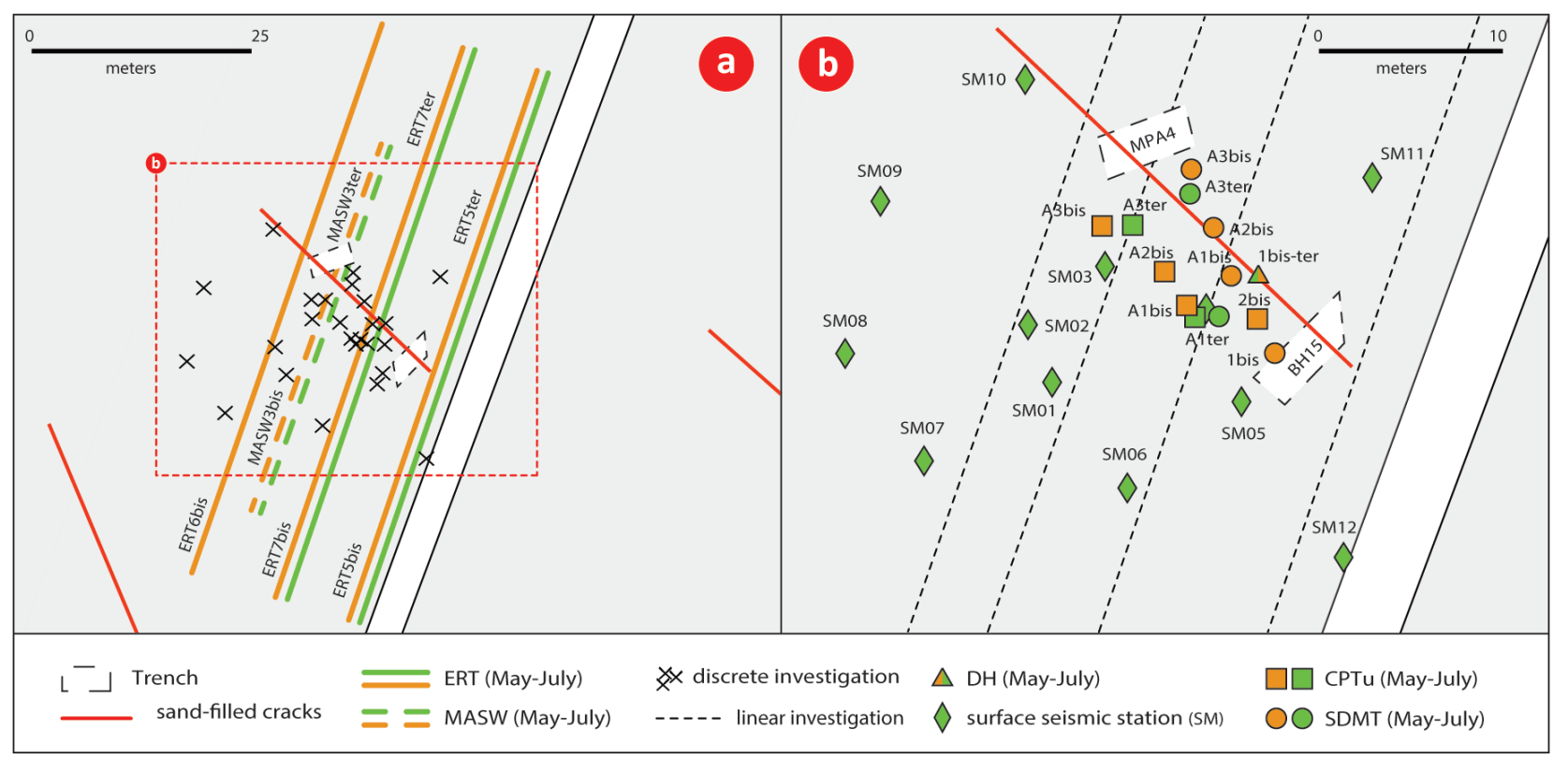

Figure 6. Map of post blast investigations at the trial Mirabello blast test site: orange color is related to the May site campaign, and green color indicates the July investigations. (a) General map; (b) detailed map.

tional PPTs were placed close to the pile to investigate the pore pressure behavior in the deepest silty sandy layers between 14 and $17 \mathrm{~m} \mathrm{bgl}$ (bottom of the pile), and one supplementary PPT was located in the center of the $3 \mathrm{D}$ geophone array at roughly $7 \mathrm{~m}$ depth (average depth of the top and bottom sensors). Two flat dilatometer blades (DMT1 and DMT1bis) and a seismic dilatometer module (SDMT1tris) were placed at about a depth of about 7.2 $\mathrm{m} \mathrm{bgl} \mathrm{(Figure} 5 \mathrm{~b}$ ) to monitor the changes in horizontal stress and in shear wave velocity during and soon after the blast. The DMT blades were not oriented with respect to any blast points, because the orientation of the dilatometer blade does not influence the test results, as indicated in a study on anisotropic horizontal stress conditions by Marchetti et al. (1987).

In April and May 2016 the supplementary boreholes, piezometer, CPTu, SDMT and DH tests were performed together with complementary compositional analyses in order to better characterize the blast zone before the detonations. In April 2016 the pile was constructed, while a month later the preblast CASE test was carried out. In May 2016 blast holes, profilometers, piezometers, DMT blades, SDMT module and in-hole geophones were also installed, while the explosive was charged the day of the blast tests, May 18, 2016. The equipment for both the discrete and areal topographical surveys and the surface seismic stations were also placed the day of the blast tests. During and/or soon after each detonation each apparatus acquired data.

\subsection{Post-blast site investigation}

Two post blast site campaigns were planned at the end of May 2016 (orange lines and symbols in Figures $7 \mathrm{a}$ and $7 \mathrm{~b}$ ) and at the beginning of July 2016 (green lines and symbols in Figures $7 \mathrm{a}$ and $7 \mathrm{~b}$ ) in order to compare the variation with the time of the geotechnical and geophysical parameters before and after the blast experiment. In particular, in May four 15-m deep seismic dilatometer tests (SDMTA1bis, SDMTA2bis, SDMTA3bis, SDMT1bis), four $15-\mathrm{m}$ deep piezocone tests (CPTuA1bis, CPTuA2bis, CPTuA3bis, CPTu1bis), one $7 \mathrm{~m}$-deep down-hole test (DH1bis), and one active and one passive $V_{s}$ measurements (MASW3bis) and three geoelectrical surveys (ERT5bis, ERT6bis, ERT7bis) were executed using the same pre-blast configuration. Furthermore, in July a smaller site investigation was carried out with pairs of $15 \mathrm{~m}$-deep SDMT-CPTu tests at A1ter and A3ter locations, a $7.5 \mathrm{~m}$-deep DH $V_{s}$ test (DH1ter), and geophysical surface surveys (MASW3ter, ERT5ter, ERT7ter, SMter passive 2D array). Two exploratory trenches (Figures $7 \mathrm{a}$ and $7 \mathrm{~b}$ ) were also excavated across the 2012 sand blows and almost orthogonal with respect to their mean strike, reaching a depth of about 2.0-2.5 $\mathrm{m}$. The BH15 trench (8 $\mathrm{m}$ long) and the MPA4 trench (10 m long) were approximately 5 and $12 \mathrm{~m}$, respectively, from the blast center. These trenches were used: a) to identify possible deformational features (fractures and sand vents) related to the 2016 blast test (BH15 trench); b) to characterize the fracture/conduit liquefaction features related to the 2012 earthquake (MPA4 trench); and c) to identify and date possible paleoliquefaction events (historical and older, e.g 1570-74 Ferrara 
earthquakes) potentially recorded in the stratigraphic sequence exposed in both trench walls [De Martini et al. 2012]. In this respect sedimentological, petrographical and compositional analyses were also planned in order to improve the detail of the results in terms of identification and characterization of different stratigraphic units.

\section{Preliminary results}

\subsection{Pre-blast results}

The supplementary site investigation performed in April 2016 confirmed the preliminary geotechnical model obtained in January (Figure 4). On average the topsoil $(\mathrm{CH})$ was confined between 0 and $1 \mathrm{~m} \mathrm{bgl}$, while the silty clay $(\mathrm{CH})$ was encountered from 1 to $4 \mathrm{~m}$ bgl. The latter layer is highly plastic (plasticity index $P I \approx 31-58 \%$ ), has a fine content $F C \approx 100 \%$ and contains a peaty layer (3.30-3.50 m bgl) that the radiocarbon datings (sample 330 Conventional age $1030 \pm 30$ yr BP, sample 340 Conventional age $1080 \pm 30 \mathrm{yr}$ BP; sample 330 2sigma calibrated age 900-1120 A.D., sample 340 2sigma calibrated age 890-1020 A.D.; calibration from Reimer et al. [2013]) attributed to 890-1120 AD [Servizio Geologico Sismico e dei Suoli, Regione Emilia-Romagna 2016]. The clayey silt with sand (CL-CH) was plastic ( $P I \approx 23-27 \%)$, had a high $F C \approx 70-80 \%$, and was approximately confined between 4 and $6 \mathrm{~m}$ bgl. The fluvial Apenninic deposits (ML-SM) between 6 to $8 \mathrm{~m} \mathrm{bgl}$ were composed of silty sand and sandy silt with low plasticity $(P I \approx 5-9 \%)$ and $F C \approx 25-75 \%$. Finally, two different paleochannels of the Po River, both composed of non-plastic silty sand, were found: the upper one (SM) from 8 to $17 \mathrm{~m} \mathrm{bgl}(F C \approx$ 20-35\%), and the lower one (SM) from 17 to $20 \mathrm{~m} \mathrm{bgl}$ $(F C \approx 25-30 \%)$.

ERT profiles also confirmed this geotechnical model, as shown in Table 2 . Besides the relatively higher values of electrical resistivity $\rho$ in the surficial dry crust $(\mathrm{CH})$, the fine-grained deposits (i.e. $\mathrm{CH}$ and CL-CH) provide low values of resistivity $(\rho \approx 6-14$ $\mathrm{Ohm} \cdot \mathrm{m}$ ). The lower values can be related to the presence of the ground water table located, at the time of

\begin{tabular}{lccc}
\hline depth $(\mathbf{m})$ & $\begin{array}{c}\boldsymbol{\rho}_{\text {pre }} \\
(\mathbf{O h m} \cdot \mathbf{m})\end{array}$ & $\begin{array}{c}\boldsymbol{\rho}_{\text {post May }} \\
(\mathbf{O h m} \cdot \mathbf{m})\end{array}$ & $\begin{array}{c}\boldsymbol{\rho}_{\text {post July }} \\
(\mathbf{O h m} \cdot \mathbf{m})\end{array}$ \\
\hline $0-1$ & $30-40$ & $11-15$ & $10-14$ \\
$1-4$ & $10-14$ & $6-10^{*}$ & $6-10$ \\
$4-6$ & $6-10$ & $6-10^{*}$ & $6-10$ \\
$6-8$ & $10-20$ & $5-15^{*}$ & $8-18$ \\
$8-15$ & $22-33$ & $10-20^{*}$ & $15-25$ \\
\hline
\end{tabular}

*Lost of lateral continuity

Table 2. Average values of the electrical resistivity before $\left(\rho_{\text {pre }}\right)$ and after (May: $\rho_{\text {post May }}$ July: $\rho_{\text {post July }}$ ) the blast test.

\begin{tabular}{lccc}
\hline depth $(\mathbf{m})$ & $\begin{array}{c}\boldsymbol{q}_{\mathrm{t} \text { pre }} \\
(\mathbf{M P a})\end{array}$ & $\begin{array}{c}\boldsymbol{q}_{\mathrm{t} \text { post May }} \\
(\mathrm{MPa})\end{array}$ & $\begin{array}{c}\boldsymbol{q}_{\mathrm{t} \text { post July }} \\
(\mathrm{MPa})\end{array}$ \\
\hline $0-1$ & $0.5-1.5$ & - & $0.4-0.8$ \\
$1-4$ & $0.8-1.8$ & $0.7-1.6$ & $0.7-1.6$ \\
$4-6$ & $0.6-1.1$ & $0.4-0.9$ & $0.6-1.0$ \\
$6-8$ & $0.6-2.5$ & $0.5-2.0$ & $0.8-2.1$ \\
$8-17$ & $6.0-11.5$ & $4.5-11.0$ & $5.5-11.0$ \\
$17-20$ & $13.0-18.0$ & - & - \\
\hline
\end{tabular}

Table 3. Average values of the corrected cone tip penetration resistance before $\left(q_{t \text { pre }}\right)$ and after (May: $q_{t \text { post May }}$ July: $\left.q_{t \text { post July }}\right)$ the blast test.

\begin{tabular}{lccc}
\hline depth $(\mathbf{m})$ & $\begin{array}{c}\boldsymbol{K}_{\mathrm{D} \text { pre }} \\
(-)\end{array}$ & $\begin{array}{c}\boldsymbol{K}_{\mathrm{D} \text { post May }} \\
(-)\end{array}$ & $\begin{array}{c}\boldsymbol{K}_{\text {D post July }} \\
(-)\end{array}$ \\
\hline $0-1$ & $15.0-50.0$ & $10.0-40.0$ & $15.0-45.0$ \\
$1-4$ & $4.5-17.5$ & $3.5-12.0$ & $4.5-13.0$ \\
$4-6$ & $2.0-4.5$ & $1.5-3.0$ & $2.5-4.5$ \\
$6-8$ & $1.5-3.5$ & $1.0-2.5$ & $1.5-3.0$ \\
$8-17$ & $2.5-6.5$ & $1.5-5.0$ & $2.0-6.0$ \\
$17-20$ & $3.5-5.0$ & - & - \\
\hline
\end{tabular}

Table 4. Average values of the horizontal stress index before $\left(K_{D \text { pre }}\right)$ and after (May: $K_{D \text { post May }}$ July: $K_{D \text { post July }}$ ) the blast test.

\begin{tabular}{lccc}
\hline depth (m) & $\begin{array}{c}\boldsymbol{M}_{\text {pre }} \\
(\mathbf{M P a})\end{array}$ & $\begin{array}{c}\boldsymbol{M}_{\text {post May }} \\
\text { (MPa) }\end{array}$ & $\begin{array}{c}\boldsymbol{M}_{\text {post July }} \\
(\mathbf{M P a})\end{array}$ \\
\hline $0-1$ & $10.0-30.0$ & $6.0-20.0$ & $10.0-22.0$ \\
$1-4$ & $15.0-40.0$ & $12.0-30.0$ & $13.0-30.0$ \\
$4-6$ & $3.0-8.0$ & $2.0-8.0$ & $2.5-8.0$ \\
$6-8$ & $2.0-20.0$ & $2.0-15.0$ & $3.0-20.0$ \\
$8-17$ & $25.0-85.0$ & $20.0-60.0$ & $25.0-60.0$ \\
$17-20$ & $55.0-90.0$ & - & - \\
\hline
\end{tabular}

Table 5. Average values of the constrained modulus before $\left(M_{\text {pre }}\right)$

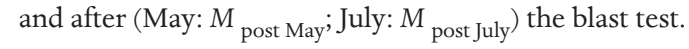

\begin{tabular}{lccc}
\hline depth $(\mathbf{m})$ & $\begin{array}{c}\boldsymbol{V}_{\boldsymbol{s} \text { pre }} \\
(\mathbf{m} / \mathbf{s})\end{array}$ & $\begin{array}{c}\boldsymbol{V}_{\boldsymbol{s} \text { post May }} \\
(\mathbf{m} / \mathbf{s})\end{array}$ & $\begin{array}{c}\boldsymbol{V}_{\boldsymbol{s} \text { post July }} \\
(\mathbf{m} / \mathbf{s})\end{array}$ \\
\hline $0-1$ & $75-115$ & $70-90$ & $65-95$ \\
$1-4$ & $120-180$ & $85-125$ & $100-130$ \\
$4-6$ & $120-170$ & $100-140$ & $110-150$ \\
$6-8$ & $140-170$ & $115-160$ & $130-180$ \\
$8-17$ & $160-260$ & $140-240$ & $155-260$ \\
$17-20$ & $200-260$ & $220-270$ & $235-275$ \\
\hline
\end{tabular}

Table 6. Average values of the shear wave velocity before $\left(V_{s \text { pre }}\right)$

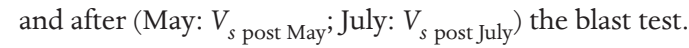

ERT execution (February 2016), at GWT $\approx 4.2 \mathrm{~m}$ bgl. In contrast the coarser sediments (i.e. ML-SM and SM) detect higher values of resistivity $(\rho \approx 10-33 \mathrm{Ohm} \cdot \mathrm{m})$, with the $\rho$ value increasing approximately as the fine content decreases.

The following tables summarize the average preblast geotechnical and geophysical parameters ob- 
tained for the various soil layers, in terms of corrected cone tip resistance $q_{t}$ (Table 3 ) from CPTu tests, horizontal stress index $K_{D}$ (Table 4 ) and constrained modulus $M$ (Table 5) from SDMT tests, and shear wave velocity $V_{s}$ (Table 6) from DH, MASW and SDMT.

The high variation of $V_{s}$ values within each layer can be attributed to the use of both invasive and non-invasive techniques. For example, the MASW tests can include some uncertainties because of the non-unique solution for the $V_{s}$ profile from the inversion of the dispersion curve and because the measurement involves a wider investigation volume than in-hole tests, such as DH or SDMT [Garofalo et al. 2016]. Therefore, higher variability is expected.

On average the shear wave velocity profiles from DH, MASW and SDMT are very similar in the upper $14 \mathrm{~m}$ bgl since the deviation, defined as the maximum difference between $V_{s}$ values at the same depth, is of about $20 \mathrm{~m} / \mathrm{s}$. The $V_{s}$ profiles from the $\mathrm{DH}$ and SDMT still have a maximum deviation of $20 \mathrm{~m} / \mathrm{s}$ for depths greater than $14 \mathrm{~m}$ bgl, while MASW results have a higher variability (maximum of $70 \mathrm{~m} / \mathrm{s}$ ) when compared to the data from invasive techniques.

Moreover, the variability of the topsoil and silty clay parameters is also due to seasonal variations in water content along with fluctuation of the GWT. During the 2015-2016 dry season (from summer time up to February 2016), the presence of a shallow desiccated crust $(\mathrm{GWT} \approx 4.2 \mathrm{~m}$ ) was observed. This crust changed its mechanical properties when rainfall increased (from April 2016 GWT measured by PZ1 reached about $3.2 \mathrm{~m}$ ).

According to the preliminary liquefaction potential assessment, the low values of resistance $\left(q_{t} \approx 0.6\right.$ 2.5 $\left.\mathrm{MPa}, K_{D} \approx 1.5-3.5\right)$ and stiffness $(M \approx 2.0-20.0 \mathrm{MPa}$, $V_{s} \approx 140-170 \mathrm{~m} / \mathrm{s}$ ) in the silty sand and sandy silt (MLSM) confirmed the high liquefaction susceptibility of the fluvial Apenninic deposits. After the upper paleochannel of the Po River (SM) is encountered, the safety factor against liquefaction $(F s)$ starts to increase in the silty sands until the highest values $(F s>1.2)$ are encountered in the Syn-Glacial braided Po River deposits $\left(\mathrm{SM} ; q_{t} \approx 13.0-18.0 \mathrm{MPa}, K_{D} \approx 3.5-5.0, \mathrm{M} \approx 55.0-90.0\right.$ $\mathrm{MPa}, V_{s} \approx 200-260 \mathrm{~m} / \mathrm{s}$ ).

Whereas the MASW linear arrays derived a dispersion curve in the high-frequency range (from 8 to $25 \mathrm{~Hz}$ with apparent phase velocity spanning from 150 to $85 \mathrm{~m} / \mathrm{s}$ ), the passive $2 \mathrm{D}$ arrays were able to investigate the dispersion properties in a lower range of frequencies (1.2-5 Hz and 4-15 Hz for the big and small 2D array, respectively). The combined dispersion curves based on array analysis, together with the ground motions recorded by the accelerometers during the blast tests, will be presented in the future. Furthermore, the microtremor data recorded by the seismic stations within the $2 \mathrm{D}$ arrays were also used to compute the $\mathrm{H} / \mathrm{V}$ noise spectral ratios [Nakamura 1989, Milana et al. 2014]. The H/V ratios detect two low amplification frequency peaks likely related to the deepest layers not investigated by the other geotechnical and geophysical tests: the first one at about $0.7 \mathrm{~Hz}$ may refer to the impedance contrast $(\approx 80-100 \mathrm{~m} \mathrm{bgl}$ ) between the Bazzano Subsynthem (AES6) and the undifferentiated portion of the Upper Emiliano-Romagnolo (AESi), while the second spectral $\mathrm{H} / \mathrm{V}$ peak at about $<0.3 \mathrm{~Hz}$ may correspond to the impedance contrast $(\approx 800 \mathrm{~m}$ bgl) between the Marine Quaternary (QM) and the Middle-Upper Pliocene (P2). A third uncertain peak is also present at $0.17 \mathrm{~Hz}$ near to the eigen-frequency of the velocimeter $(0.2 \mathrm{~Hz})$ and could be related to a deeper contact between Pliocene-Quaternary deposits and Miocene marls [Mascandola et al. 2017]. Further details on the abovementioned stratigraphical units can be found in Minarelli et al. [2016].

Finally, a pre-blast dynamic CASE load test on the test micropile was performed on May 2016. The results will be illustrated in terms of axial resistance and load-settlement curves due to the uncertainties and the factors that may affect the end bearing capacity interpreted from the CASE test and the CAPWAP (CAse Pile Wave Analysis Program) results. Before the blast the CASE test yielded a shaft resistance of $630 \mathrm{kN}$, developed from the uppermost part of the subsoil to around $11 \mathrm{~m} \mathrm{bgl} \mathrm{where} \mathrm{the} \mathrm{values} \mathrm{strongly} \mathrm{decreased.}$ In terms of load-settlement curve the CASE test had a very stiff response that however was not possible to reproduce using the site characterization data. This may be in part due to the fact that the CASE test was not calibrated based on a static load test and also the fact that the pile was CASE tests did not produce sufficient deflection to fully mobilize resistance deeper in the pile.

\subsection{Blast results}

On the $18^{\text {th }}$ of May 2016 the two sequences of blast charges were detonated separately. The first blast followed the planned configuration, while for the second blast, performed five hours later, the charges in each hole were reduced to $2.5 \mathrm{~kg}$ and located only at a single depth, approximately $6 \mathrm{~m}$ bgl, because of damage to the blast holes from the first blast. Nevertheless, the generation and the dissipation of the excess pore 


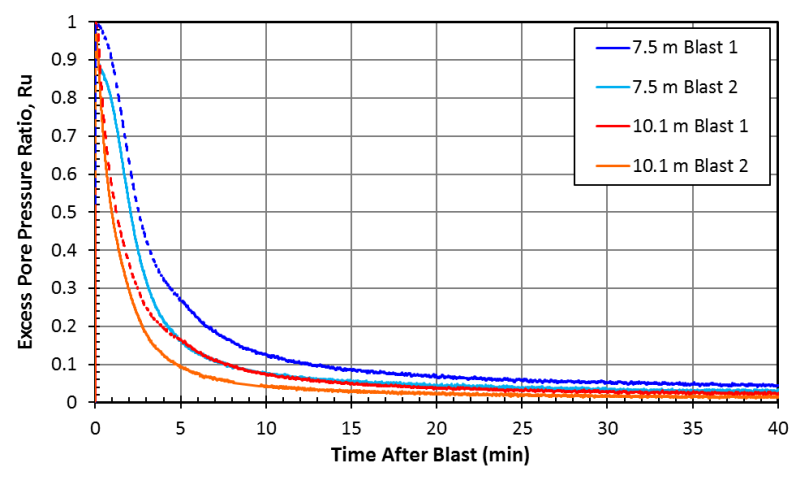

Figure 8. Excess pore pressure ratio as a function of time after blast for the PPTs located at 7.5 and $10.1 \mathrm{~m}$ bgl.

water pressure (i.e. pressure in excess of static water pressure) were similar in both the blast events, as measured by PPTs (Figure 8). With each charge detonation a transient pulse was produced which led to a progressive increase in the pore pressure ratio $R_{u}$ (ratio between the excess pore pressure and the initial vertical effective stress) until complete (or almost complete) liquefaction was achieved with $R_{u}$ values of 0.8-1.0 between 6 and $10 \mathrm{~m}$ bgl. For the first blast, as confirmed also by DMT data, $R_{u}$ decreased to below 0.1 , after approximately 15 minutes whereas this occurred in about 10 minutes for the second detonation (Figure 8).

Liquefaction was also proved by the presence of seven sand boils (Figure 9) around the test area (C1 to $\mathrm{C7}$, Figure 5b), that were sampled for granulometric and compositional analyses. Preliminary laboratory information detected that the blast-induced sand blows belongs to the fluvial Apenninic deposits (6 to $8 \mathrm{~m} \mathrm{bgl}$ ).

The velocimeters close to the charges (up to $60 \mathrm{~m}$ from the blast center), the in-hole 3D geophone array and the surface array of 48 vertical geophones saturated during both the blast sequences, while all the accelerometers properly acquired the data for each pulse (Figure 10). For the first detonation the surface vibration data show horizontal and vertical peak ground accelerations (PGA) of about $0.6 \mathrm{~g}$ and $1.7 \mathrm{~g}$, respectively, at $20 \mathrm{~m}$ from the center of the blast zone. Due to the smaller charges, the second blast recorded lower $P G A$ values that are approximately equal to $0.36 \mathrm{~g}$ and 0.55 $\mathrm{g}$ for horizontal and vertical components, respectively, at $20 \mathrm{~m}$ from the center of the blast zone. In both cases the blast-induced ground motion attenuated rapidly with distance, and the vertical component reached values smaller than $0.1 \mathrm{~g}$ (first blast) and $0.02 \mathrm{~g}$ (second blast) about $160 \mathrm{~m}$ distance (Figure 10).

Velocity time histories were also determined for each component by integrating the acceleration time

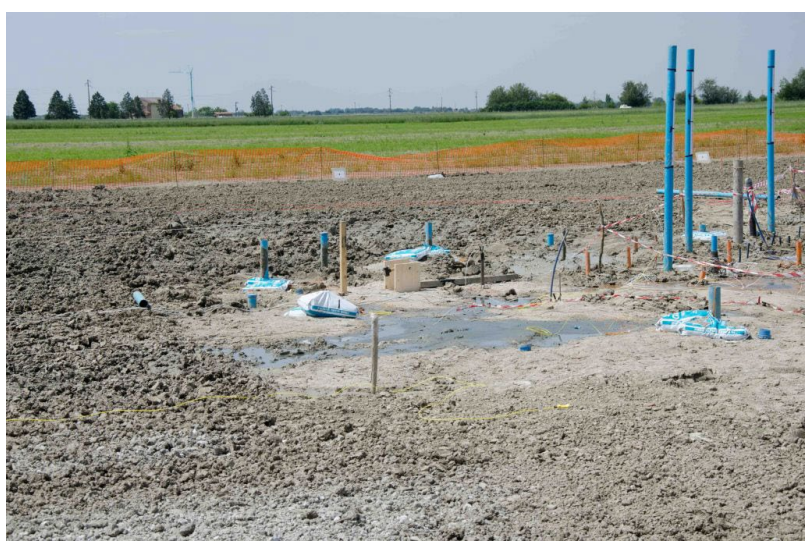

Figure 9. Blast-induced sand boils after the first detonation.

histories. The PPV parameter provides an exponentially decreasing trend, consistent with other field tests [Kato et al. 2015]. PPV shows similar values for the first and second shots of the blast experiment. Indeed for both shots the seismic station situated at $20 \mathrm{~m}$ from the center of the blast zone shows a $P P V$ of approximately 0.1 and $0.08 \mathrm{~m} / \mathrm{s}$ (for horizontal and vertical component, respectively). At a distance of $160 \mathrm{~m}, \mathrm{PPV}$ values decrease below $0.004 \mathrm{~m} / \mathrm{s}$ for both the vertical and horizontal components (Figure 10).

Despite the rectangular form and the small size of the nearly flat area of Mirabello trial site, TLS and SfM analyses aimed to obtain soil deformation via multi-temporal models and model comparison was not simple. Strong limitations were indeed imposed due to the presence of several researchers and instruments at the site in the blast area occluding targets. Therefore, the reconstruction of a detailed final model was incomplete over the area. Nevertheless, the results of the analyses clearly describe a $10 \mathrm{~m}$-diameter circular deformed area settling toward the center (Figure 11). Polyorks (Innovmetrics) and Photoscan software (AgiSoft) were used for data processing. In Figure 11 the values refer to the vertical displacements, and the contouring map clearly describes a pattern where the main differences are contained within a circular area (red dashed line). After the first blast the ground surface subsided about $15-20 \mathrm{~cm}$ (and more) providing a pattern clearly visible and centered in the zone where detonation occurred. Soil settlements decrease with distance reaching negligible values at $10 \mathrm{~m}$ from the center of the blast zone. The test pile settled about $1.5-2.0 \mathrm{~cm}$. After the second blast a pattern similar to the one observed in Figure 11 was observed: a circular 20 m-diameter zone was involved showing maximum vertical displacements of about $10-12 \mathrm{~cm}$. The test pile showed no movement at all. Additional models are ongoing and they will be pro- 

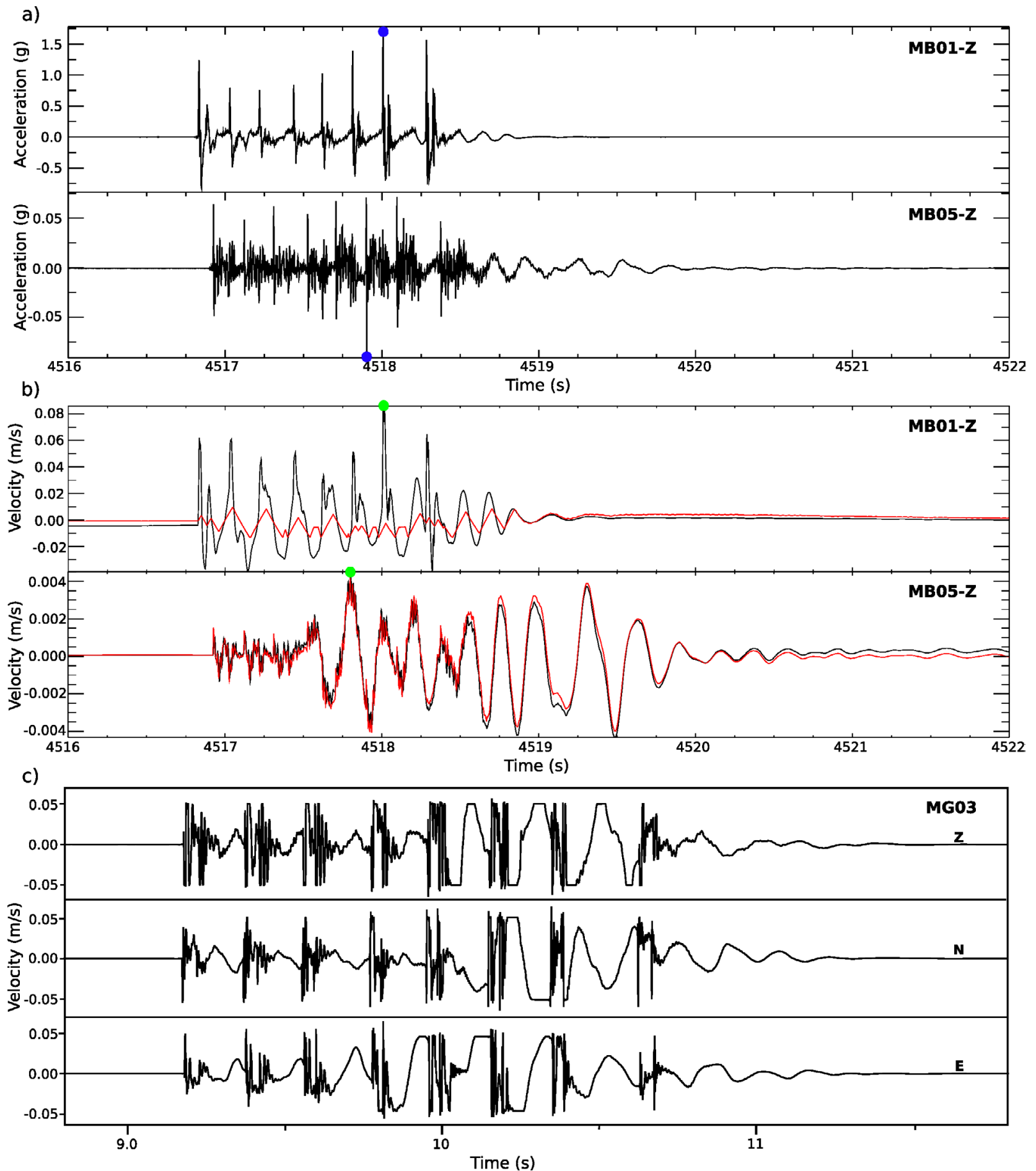

Figure 10. Signals recorded during the first blast test by vertical components at MB01 and MB05 (a) accelerometers, located at about 20 and $160 \mathrm{~m}$ from the center of explosions, respectively. The blue dots show the PGA recorded by the two stations (1.7 $\mathrm{g}$ and $0.09 \mathrm{~g}$, respectively); (b) velocity time histories recorded by MB01 and MB05 stations. The black curves in (b) show the velocity signals obtained by integrating the acceleration time histories shown in (a), while the red curves are the recordings by velocimeter sensors (saturated for MB01 station ). Green dots show the $P P V$ values $(0.08 \mathrm{~m} / \mathrm{s}$ and $0.004 \mathrm{~m} / \mathrm{s}$ for MB01 and MB05, respectively); (c) velocity time histories recorded by MG03 in-hole triaxial geophone (located at a distance of $10 \mathrm{~m}$ from the blast center, at a depth of $6.3 \mathrm{~m} \mathrm{bgl}$ ). During the blast test, a clear signal saturation is visible on all MG03 components.

vided in the future after repeatability tests in order to overcome possibly systematic errors.

Finally, the detailed models from remote sensing made it possible to extract point data that correspond to the profilometers: after the first blast relevant surface settlements of about $20-22 \mathrm{~cm}, 18-20 \mathrm{~cm}, 12-14 \mathrm{~cm}$ and 4-6 cm were estimated, corresponding to MPA1, MPA2, MPA3 and MPA4, respectively (see Figure 11).

The general findings of the discrete ground surface soil settlement measurements met expectations with the maximum amount of subsidence of $34 \mathrm{~cm}$ occurring in the center of the blast zone (first blast: 
a)
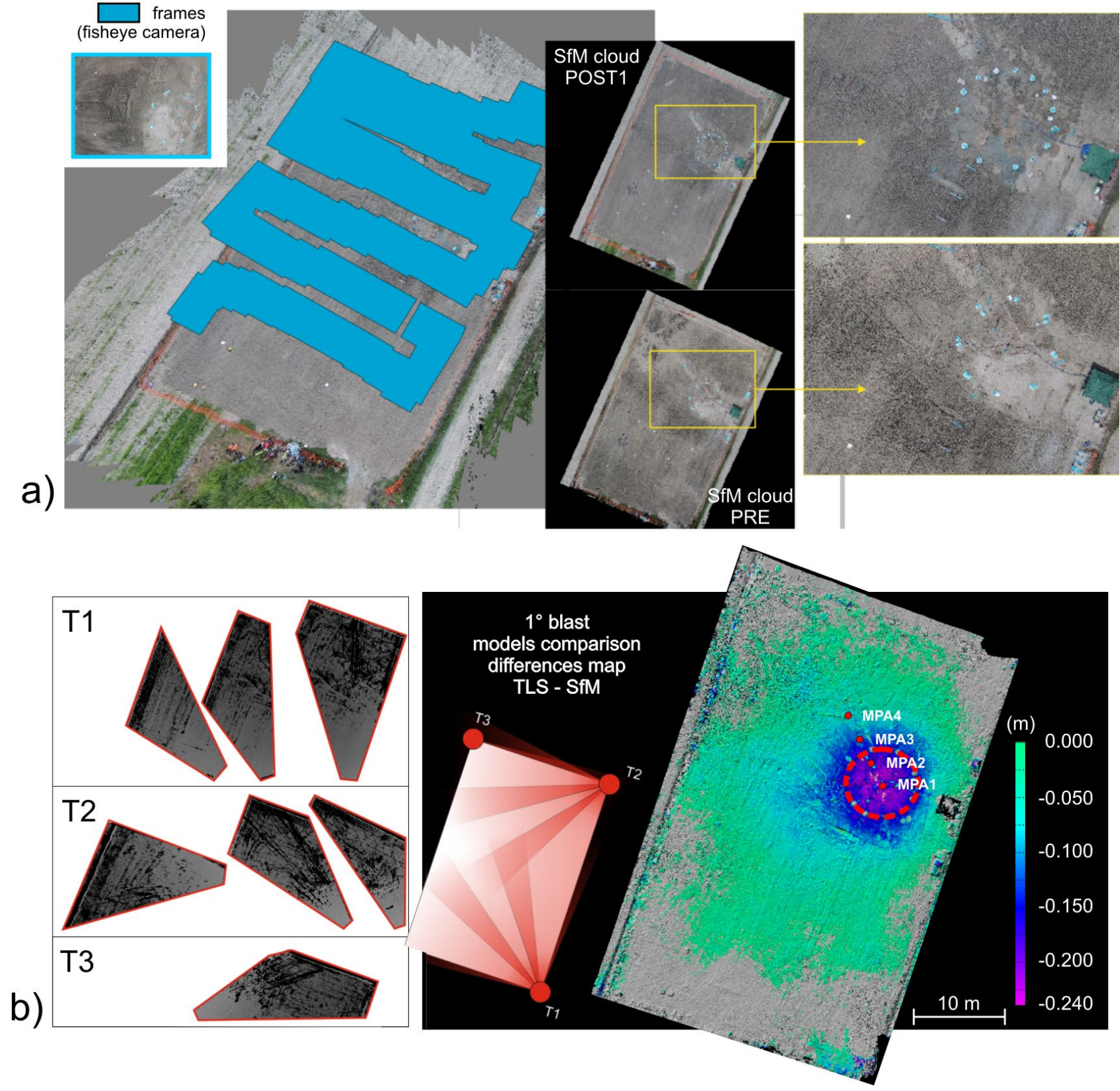

Figure 11. TLS and SfM methodologies to observe and measure surface displacements. (a) The images were acquired using flying drone, frames and camera position in the space; the point clouds were obtained from data analysis using Phostoscan software; (b) the TLS point clouds were acquired scanning from three stationary points ( $\mathrm{Ti}$ ) and model reconstruction, while the map of elevation differences was obtained by comparing multi-temporal models before and after the first blast.

$19 \mathrm{~cm}$; second blast: $15 \mathrm{~cm}$ ). As the distance from the center of the blast zone increased, the settlement amounts recorded decreased, and the highest settlements were recorded within the blast circle. Due to preconsolidation, the settlement after the second blast was less even though the recording interval was longer (roughly 13 hours compared to 5 hours). Both detonations display similar settlement curves. These curves represent the dissipation of the excess pore pressure that developed during the liquefaction phase. As the pore pressures decreased, the settlement increased. In addition, some creep settlement may occur after pore pressures are dissipated as the sand moves into a denser arrangement.

Similar to the discrete ground surface settlement data, the discrete settlement data with respect to depth decreased as the distance from the center of the blast zone increased, and the highest settlements were recorded within the blast circle. Figure 12 illustrates the ground settlement based on profilometer measurements after the first blast: vertical ground displacements were measured as $19 \mathrm{~cm}$ at MPA1, $16.5 \mathrm{~cm}$ at MPA2, $6.7 \mathrm{~cm}$ at MPA3 and $2.2 \mathrm{~cm}$ at MPA4, and they provide reasonable agreement when 


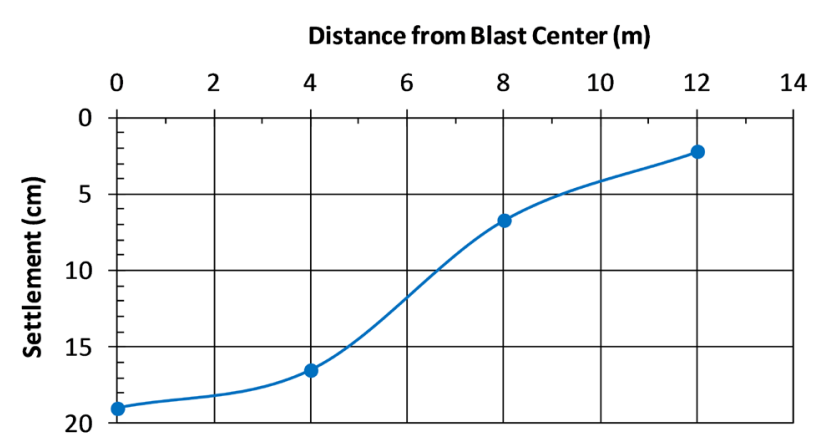

Figure 12. Profilometer settlement versus distance results after the first blast.

compared also with the areal topographical surveys.

Moreover, the profilometer at the center of the blast zone (MPA1) recorded a combined settlement of about $36 \mathrm{~cm}$ after the detonations, and $38 \mathrm{~cm}$ one week after the blasts. Most of the consolidation with respect to depth occurred in the liquefied layers and layers with elevated pore pressures between 6 and $12 \mathrm{~m}$ bgl.

Pile data interpretation is still ongoing. However, some preliminary observations are possible. Blast-induced liquefaction led to negative skin friction and pile settlement. Negative friction in the cohesive soil layers above $6 \mathrm{~m}$ was similar to the positive friction based on the undrained shear strength and that from the CASE test. As the liquefied layer settled owing to the dissipation of the excess pore pressures, the increased effective stress allowed the negative skin friction to progressively increase at the silty sand and sandy silt-pile interface. Similar to previous full-scale blast liquefaction tests [Rollins and Hollenbaugh 2015, Rollins and Strand 2006] the Mirabello results suggests that after consolidation, the average negative skin friction in the liquefied layers was 40 to $50 \%$ of the positive pre-liquefaction skin friction.

\subsection{Post-blast results}

The representative values of the post-blast geotechnical and geophysical parameters measured in the two site campaigns (May 2016 and July 2016) are reported in Tables 2, 3, 4, 5, 6. The corrected cone resistance $q_{t}$ (Table 3 ), the horizontal stress index $K_{D}$ (Table 4), the constrained modulus $M$ (Table 5), and shear wave velocity $V_{s}$ (Table 6) evidenced a reduction in soil resistance and stiffness within the liquefied layer of the fluvial Apenninic silty sands and sandy silt after the execution of blast tests, that was partially recovered with time. A certain decrease is also detectable in the silty sand layer of the upper paleochannel of the Po River. These trends can also be observed from Figure 13 where plots are provided showing the average and related lower and upper bound deviation values for the various soil layers based on the field tests.

In addition, ERT survey (Table 2) observed a reduction in electrical resistivity in the same liquefied layer after blast tests and a similar partial recovery with time. A similar resistivity variation was also observed within the lower silty sandy layer. Imaged resistivity differences from one of the ERT tomograph surveys, after the blast tests is shown in Figure 14. The observed variations can be related to the changes in compaction of the layers of interest. In both a variation in the lateral continuity of the layers can be also observed in the tomograms after the blast tests.

Moreover, all the tests also indicate a reduction in the values of resistance and stiffness parameters $\left(\rho, q_{t}\right.$, $K_{D}, M, V_{s}$ ) in the upper $6 \mathrm{~m}$ bgl, probably due to the tendency for blast-induced cracking and the rise of the liquefied silty sand and sandy silt towards the surface.

The July post-blast CASE test on the pile provided very similar results when compared to the pre-blast CASE
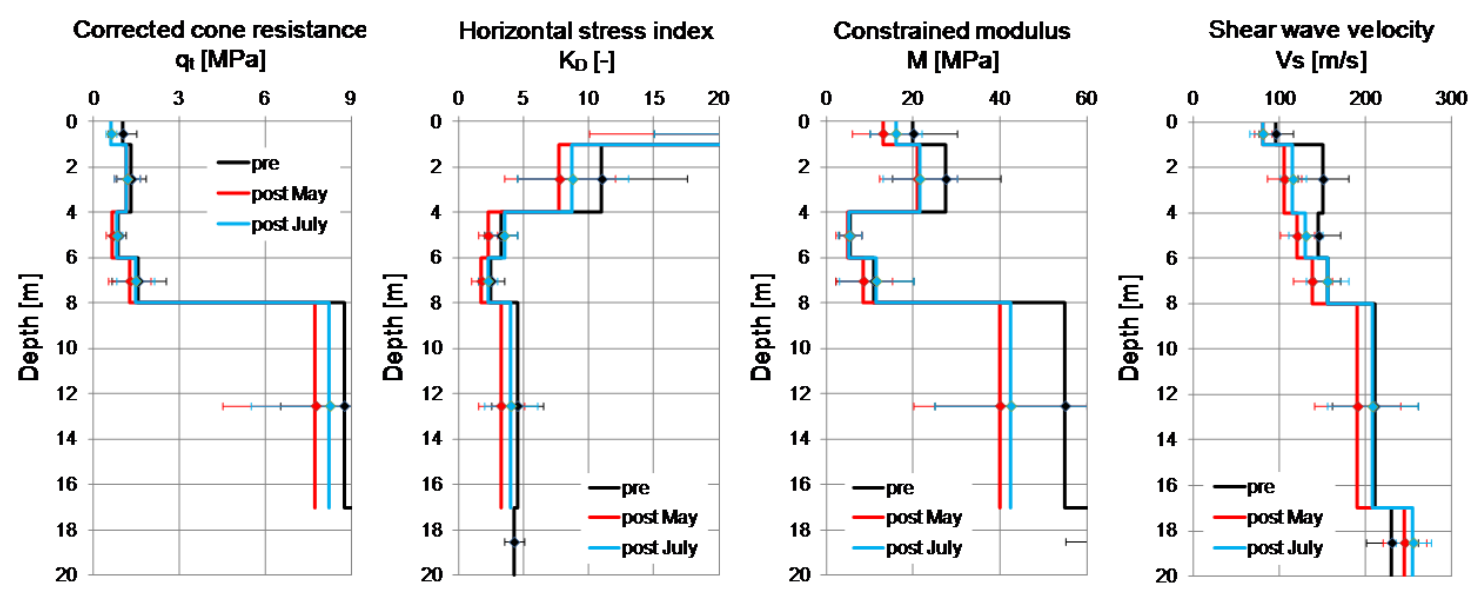

Figure 13. Variation of the geotechnical and geophysical parameters before (black line) and after (red line for the May results and light blue for the July data) the blast test, obtained from CPTu, SDMT, DH and MASW tests in the trial area of Mirabello. 


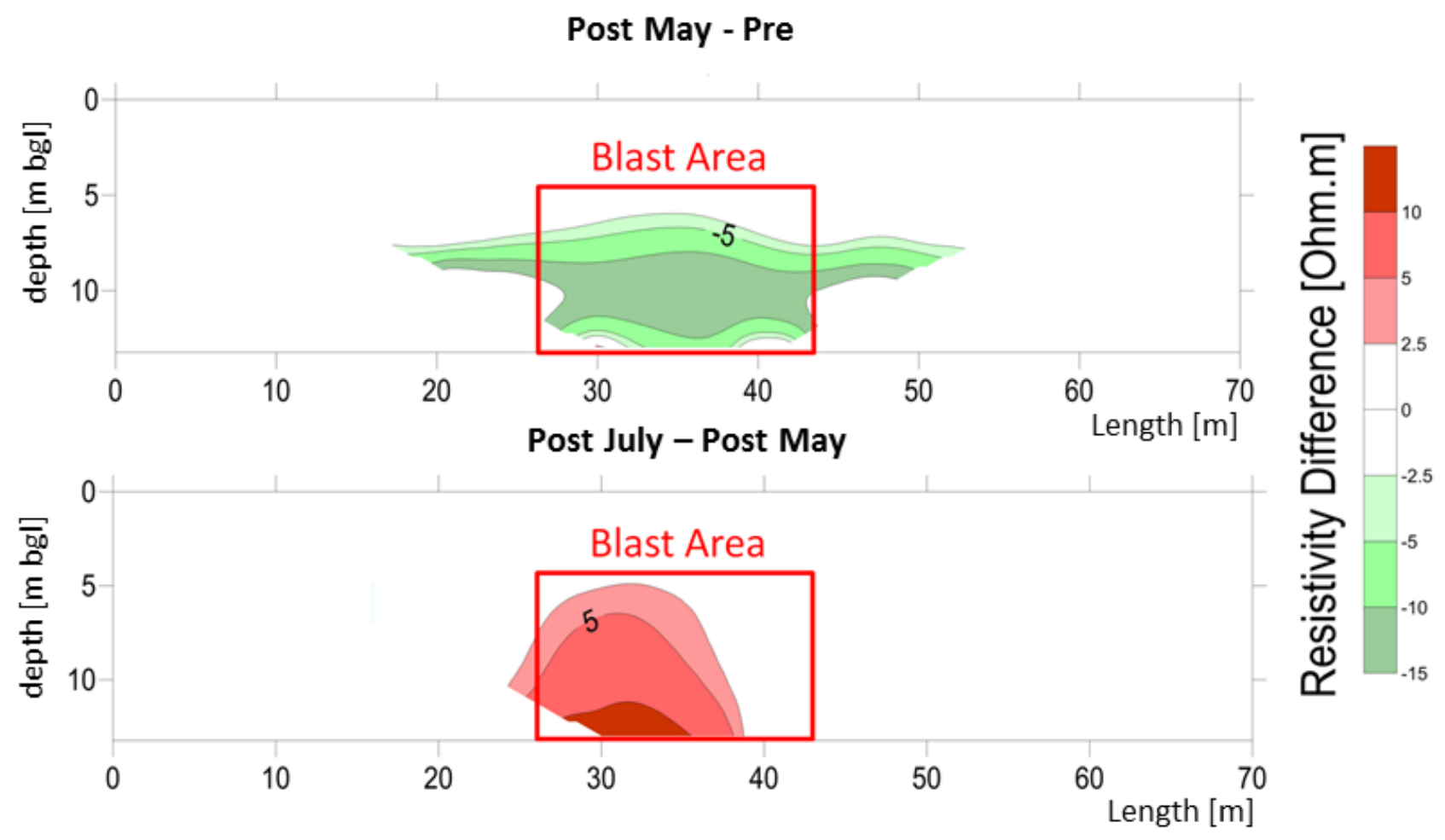

Figure 14. Imaged resistivity differences (from top to bottom Post-May minus Pre-February and Post-July minus Post May) from one of the ERT surveys, within the fluvial Apenninic deposits and the upper paleochannel of the Po River within the blast zone.

test in terms of axial resistance $(630 \mathrm{kN})$. Nevertheless, after the detonations the first $7 \mathrm{~m}$ of pile became practically ineffective in developing side resistance that was instead transferred entirely to the deeper section of the pile (the last $10 \mathrm{~m}$ ). A similar trend was visible from the May postblast CASE test that yielded a much lower shaft resistance $(491 \mathrm{kN})$. Moreover, the post-blast CASE tests showed how the pile-soil interaction is decidedly less rigid due to induced liquefaction. These results can be explained by the blast-induced liquefaction that initially decreased soil resistance and stiffness, but these properties partially recovered with time as confirmed by the post-blast site characterization campaigns.

At the end of July 2016 exploratory trenches, 2.0-2.5 m-deep, were also dug (see Figure 7 for their location). The trench walls were first cleaned, then a regular grid was applied and a set of detailed pictures was taken to better record the nature of the deposits and the sedimentary/deformation-structures that were exposed. This dataset was then used to derive high resolution trench photo-mosaics from SfM image-based modeling. A stratigraphic $\log$ (Figure 15) was drawn at 1:20 scale showing: a) a reworked layer at the surface related to post-2012 plowing and set up activities for the blast test (unit A: plowed horizon and 2012 sands mixed up); b) a sedimentary sequence dominated by hazel to brown silt to clay deposits of fluvial origin (mainly overbank sediments, see Figure 15), usually massive with only one laminated clayey layer (unit D); and c) several fractures, up to a few $\mathrm{cm}$ wide and almost vertical, that were filled by medium to fine grey sand, reaching the 2012 sand blow layer, up to $25 \mathrm{~cm}$ thick (unit $S$ in Figure 15). Several sediment samples were collected from the trench walls (Figure 15). Sedimentological, compositional and petrographical analyses are in progress, with particular attention to the sands collected from different fractures and from the 2012 sand blow on the trench walls. However, some preliminary observations can be provided. The trench walls show the presence of several fractures used by the liquefied sands in 2012 to reach the surface. These fractures are responsible for producing the multiple aligned sand volcanos investigated. The ongoing analyses will help in identifying and discriminating between the 2012 event sands and those of different origin possibly related to the blast test or to older liquefaction phenomena.

\section{Conclusions}

A full-scale blast-induced liquefaction test was carried out for the first time in Italy following the 2012 Emilia earthquake. The controlled blasting experiment induced liquefaction in the trial field site of the Mirabello village. In-depth pre- and post-blast site investigations were performed to characterize the site and to observe the effects produced by the blast induced liquefaction.

The measurements of excess pore pressures and 

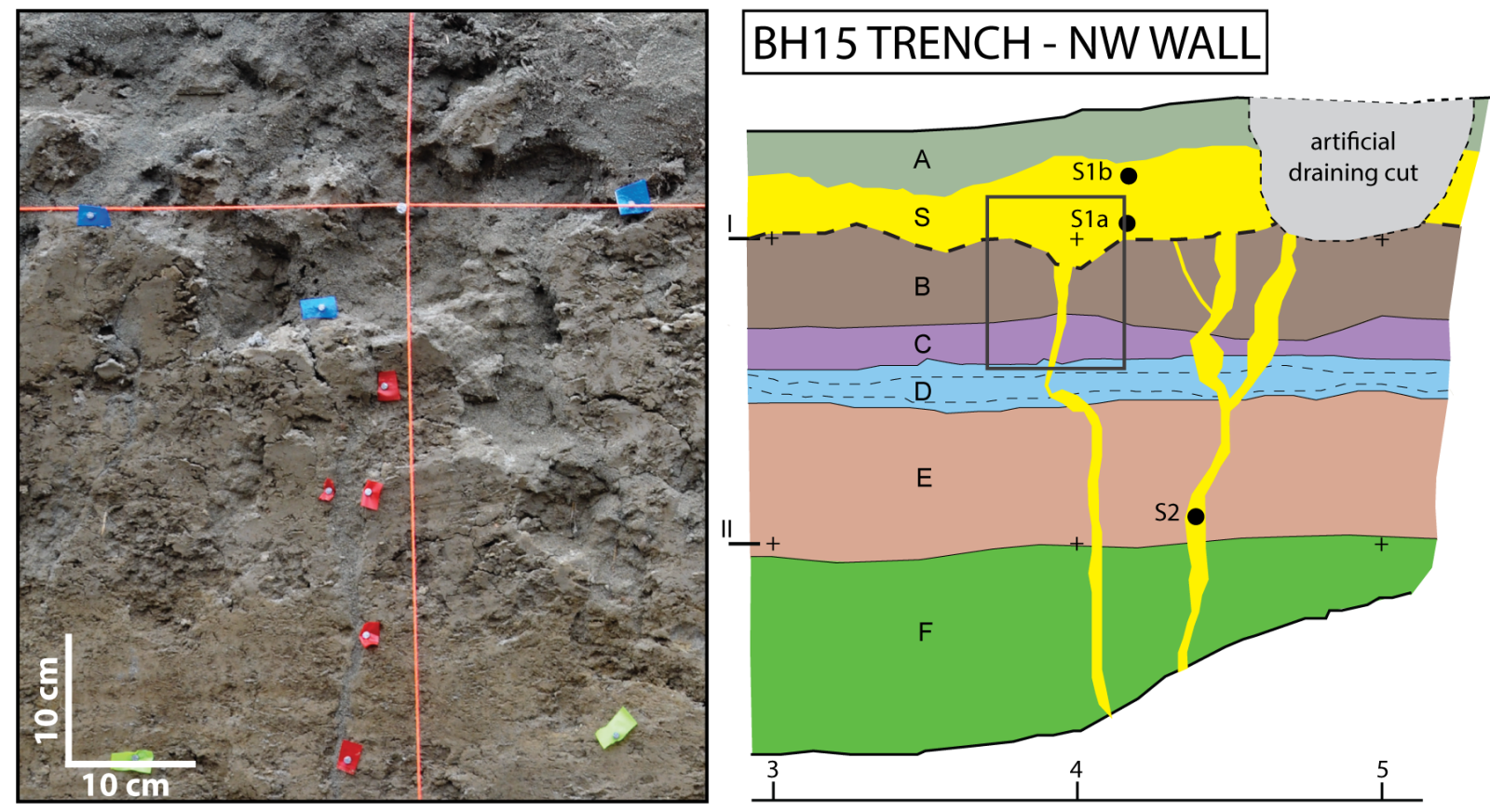

A plowed horizon and 2012 sand mixed up

S medium fine grey loose sand liquefied during 2012 earthquake

B pre-2012 plowed and soil horizon made of silty clay to clayey silt

C hazel to brown massive silt

$\mathrm{E}$ hazel to brown massive silt

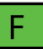

hazel clay with grey vertical bioturbated veins and sparse oxidized patches

$S_{n}$

location and code of collected samples crack filled with $\mathrm{S}$ sand laminated hazel clay

Figure 15. Detail of the NW wall of the BH15 trench (see Figures 7a and 7b for location): Detail of the 2012 sand conduit (left; see black frame on the $\log$ ) and interpreted log (right) of the 3-5 meter section.

soil deformations were used to locate the liquefied layers, that correspond to the fluvial Apenninic deposits $(6-8 \mathrm{~m} \mathrm{bgl})$ and to the upper part of a paleochannel of the Po River (8-12 m bgl).

Peak ground motion parameters $(P P V$ and $P G A$ values) attenuated rapidly from the center of the blast zone, and their trends are generally in agreement with the previous case studies.

The comparison between the pre-blast and postblast soil parameters highlighted a reduction in soil resistance and stiffness within the liquefied layers after the blast. This reduction was partially recovered with time (two months later). Invasive and non-invasive tests also showed a reduction in some soil parameters (cone tip resistance $q_{t}$ from CPTu tests; horizontal stress index $K_{D}$ and constrained modulus $M$ from SDMT; shear wave velocity $V_{s}$ from SDMT, MASW and DH test) in the upper $6 \mathrm{~m}$ bgl probably due to the tendency for the stiff clay to crack and allow the liquefied silty sand and sandy silt to rise towards the surface.

Further studies on the available dataset are ongoing in order to refine the results and to develop in-depth analyses also comparing and integrating the information derived from the different methods used.

Acknowledgements. The study was mainly funded by FIRB-Abruzzo project ("Indagini ad alta risoluzione per la stima della pericolosità e del rischio sismico nelle aree colpite dal terremoto del 6 aprile 2009", http://progettoabruzzo.rm.ingv.it/it). Special thanks to Brigham Young University for contributing to the realization of the blast test experiment in terms of personnel and technical equipment; to Geoconsult srl (Giuseppe Miceli) that partially financed the CASE tests; to the technicians from different Universities and Companies (Dave Anderson, Andrew Sparks, Roberto Bardotti, Giovanni Bianchi, Diego Franco, Constantin Diaconu) that helped in the execution and elaboration of the geotechnical and geophysical tests. A special thank also to the Mirabello Municipality (in particular the mayor, Angela Poltronieri) that made this experiment possible in collaboration with the other local authorities (Ferrara Prefecture, Emilia-Romagna Region, Ferrara Province, Local Civil Protection, Police, Fire Brigade). The authors would also like to thank the anonymous reviewers for their valuable comments and suggestions to improve the paper.

\section{References}

Amorosi, A., Bruno, L., Cleveland, D.M., Morelli, A. and Hog W. (2016). Paleosols and associated channel-belt sand bodies from a continuously subsiding late Qua- 
ternary system (Po Basin, Italy): New insights into continental sequence stratigraphy, Geological Society of America Bullettin, doi: 10.1130/B31575.1

Andrus, R.D. and Stokoe, K.H. (2000). Liquefaction resistance of soils from shear-wave velocity, J. Geotech. Geoenviron. Eng, ASCE 126 (11): 1015-1025.

Ashford, S., Rollins, K. and Lane, J. (2004). Blast-induced liquefaction for full-scale foundation testing. Journal of Geotechnical and Geoenvironmental Engineering, 130(8), 798-806.

ASTM D2487-11 (2011). Standard Practice for Classification of Soils for Engineering Purposes (Unified Soil Classification System).

Bruno, L., Amorosi, A., Severi, P. and Costagli, B. (2016). Late Quaternary aggradation rates and stratigraphic architecture of the southern Po Plain, Italy, Basin Research, doi:10.1111/bre.12174

Caputo, R. and Papathanasiou, G. (2012). Ground failure and liquefaction phenomena triggered by the 20 May, 2012 Emilia-Romagna (Northern Italy) earthquake: case study of Sant'Agostino - San Carlo - Mirabello zone, Natural Hazards and Earth System Sciences, vol. 12, no. 11, pp. 3177-3180, doi: 10.5194/nhess-12-3177-2012.

De Martini, P. M., Cinti, F.R., Cucci, L., Smedile, A., Pinzi, S., Brunori, C.A. and Molisso, F. (2012). Sand volcanoes induced by the April 6th $2009 \mathrm{Mw} 6.3$ L'Aquila earthquake: a case study from the Fossa area, Italian, J. Geosci., 131, 410-422.

Emergeo Working Group (2013). Liquefaction phenomena associated with the Emilia earthquake sequence of May-June 2012 (Northern Italy), Natural Hazards and Earth System Sciences, 13 (4), 935-947; doi: 10.5194/nhess-13-935-2013.

EN 1998-5 (2004). Eurocode 8: Design of structures for earthquake resistance - Part 5: Foundations, retaining structures and geotechnical aspects, CEN European Committee for Standardization, Bruxelles, Belgium.

Facciorusso, J., Madiai, C. and Vannucchi, G. (2016). The 2012 Emilia earthquake (Italy): geotechnical characterization and ground response analyses of the paleo-Reno river levees. Soil Dynamics and Earthquake Engineering, Vol. 86, 71-88, doi:10.1016/j.soildyn.2016.04.017

Finno, R.J, Gallant, A.P. and Sabatini, P.J., (2016). Evaluating Ground Improvement after Blast Densification at the Oakridge Landfill, Journal of Geotechnical and Geoenvironmental Engineering, ASCE, Vol. 142, No. 1, 2016, 04015054, 1-13.

Fioravante, V., Giretti, D., Abate, G., Aversa, S., Bold- ini, D., Capilleri, P., Cavallaro, A., Chamlagain, D., Crespellani, T., Dezi, F., Facciorusso, J., Ghinelli, A., Grasso, S., Lanzo, G., Madiai, C., Massimino, M. R., Maugeri, M., Pagliaroli, A., Ranieri, C., Tropeano, G., Santucci De Magistris, F., Sica, S., Silvestri, F. and Vannucchi, G. (2013). Earthquake geotechnical engineering aspects: the 2012 Emilia-Romagna earthquake (Italy), Seventh International Conference on Case Histories in Geotechnical Engineering, Chicago, 1-34.

Fontana, D., Lugli, S., Marchetti Dori, S, Caputo, R. and Stefani M. (2015). Sedimentology and composition of sands injected during the seismic crisis of May 2012 (Emilia, Italy): clues for source layer identification and liquefaction regime, Sedimentary Geol., 325, 158-167.

Garofalo, F., Foti, S., Hollender, F., Bard, P.Y., Cornou, C., Cox, B.R., Dechamp, A., Ohrnberger, M., Perron, V., Sicilia, D., Teague, D. and Vergniault, C. (2016). InterPACIFIC project: Comparison of invasive and non-invasive methods for seismic site characterization. Part II: Inter-comparison between surface wave and borehole methods, Soil Dynamics and Earthquake Engineering, 82, 241254, doi:10.1016/j.soildyn.2015.12.009.

Geotema (2014). Microzonazione sismica Livello 2 con locali approfondimenti di Livello 3, Regione Emilia-Romagna. Comune di Mirabello (FE), Relazione illustrativa e 7 tavv. (in Italian). http://www.comune.mirabello.fe.it / files/00036/relazione_ms_ mirabello.pdf

Goble, G.G., Scanlan, R.H. and Tomko, J.J. (1967). Dynamic studies on the bearing capacity of piles, Final project Report, Division of Solid Mechanics Structures and Mechanical Design School of Engineering Case Western Reserve University, Cleveland, $\mathrm{OH}$.

Gohl, W.B., Howle, J.A. and Rea, C.E. (2001). Use of controlled detonation of explosives for liquefaction testing, Fourth International Conference on Recent Advances in Geotechnical Earthquake Engineering and Soil Dynamics and Symposium in Honor of Professor W.D. Liam Finn, San Diego, California, March 26-31, 2001.

Győri, E., Tóth, L., Gráczer, Z. and Katona, T. (2011). Liquefaction and post-liquefaction settlement assessment - A probabilistic approach. Acta Geodaetica et Geophysica Hungarica 46(3): 347-369, doi:10.1556/ AGeod.46.2011.3.6

Idriss, I.M. and Boulanger, R.W. (2008). Soil liquefaction during earthquakes. EERI Report, Publ. No. MNO12, Earthquake Engineering Research Institute. 
Ishihara, K. and Yoshimine, Y. (1992). Evaluation of settlements in sand deposits following liquefaction during earthquakes, Soils and Foundations, 32(1): 173-188.

Iwasaki, T., Tokida, K., Tatsuoka, F., Watanabe, S., Yasuda, S. and Sato, H. (1982). Microzonation for soil liquefaction potential using simplified methods. Proc. of 3rd Int. Conf. on Microzonation, Seattle, 3, 1319-1330.

Kato, K., Mason, H.B. and Ashford, S.A. (2015). Ground vibration from blast-induced liquefaction testing from Christchurch, New Zealand, 6ICEGE - 6th International Conference on Earthquake Geotechnical Engineering, 1-4 November 2015, Christchurch, New Zealand.

Kayen, R., Moss, R., Thompson E., Seed, R., Cetin, K., Kiureghian, A., Tanaka, Y. and Tokimatsu, K. (2013). Shear-wave velocity-based and deterministic assessment of seismic soil liquefaction potential, J. Geotech. Geoenviron. Eng., ASCE 2013, 139(3): 407-419.

Kramer, S.L. (1996). Geotechnical Earthquake Engineering. Prentice Hall.

Lugli, S., Marchetti Dori, S. and Fontana, D., (2007). Alluvial sand composition as a tool to unravel the Late Quaternary sedimentation of the Modena Plain, northern Italy. In: Arribas J., Critelli, S., Johnsson, M.J. (Eds.), Sedimentary Provenance and Petrogenesis: Perspectives from Petrography and Geochemistry. Geological Society of America Special Paper, 420, 57-72.

Marchetti, S., Totani, G., Taddei, B. and Monaco, P. (1987). Indagini di anisotropia tensionale per la diagnosi della stabilità dei pendii. Attività di Ricerca nell'anno 1986-87, Gruppo Nazionale per il Coordinamento per gli studi di Ingegneria Geotecnica del Consiglio Nazionale delle Ricerche Comitato Nazionale per le Scienze di Ingegneria e Architettura, Ottobre 1987 (in Italian).

Mascandola, C., Massa, M., Barani, S., Lovati S., and Santulin, M. (2017). Long-Period Amplification in Deep Alluvial Basins and Consequences for Site-Specific Seismic-Hazard Analysis: An Example from the Po Plain (Northern Italy), Bulletin of Seismological Society of America, doi: $10.1785 / 0120160166$

Milana, G., Bordoni, P., Cara, F., Di Giulio, G., Hailemikael, S., and Rovelli, A. (2014). 1D velocity structure of the Po River plain (Northern Italy) assessed by combining strong motion and ambient noise data, Bulletin of Earthquake engineering, 12(5),
2195-2209.

Minarelli, L., Amoroso, S., Tarabusi, G., Stefani, M. and Pulelli, G. (2016). Down-hole geophysical characterization of middle-upper Quaternary sequences in the Apennine Foredeep, Mirabello, Italy, Annals of Geophysics, ISSN: 2037-416X, 59(5), S0543, doi:10.4401/ag-7114

Monaco, P., Marchetti, S., Totani, G. and Calabrese, M. (2005). Sand liquefiability assessment by Flat Dilatometer Test (DMT), Proc. XVI ICSMGE, Osaka, 4: 2693-2697.

Nakamura, Y. (1989). A method for dynamic characteristics estimation of subsurface using microtremors and the ground surface, Q. Rept. RTRI Japan, 30, 25-33.

Pyke, R., Seed, H.B. and Chan, C.K. (1975). Settlement of sands under multidirectional shaking, Journal of the Geotechnical Engineering Division 101(4):379-398.

Regione Emilia-Romagna (2012). Carta degli effetti di liquefazione osservati dopo i terremoti del 20 e 29 Maggio 2012, http: / / geo.regione.emilia-romagna. it/gstatico/ documenti/liq2012/MAPPA_LIQUEFAZIONI_01.pdf

Regione Emilia-Romagna (2013). Sisma 2012 - Studi sismici, Ordinanza n. 70 del 13/11/2012 e cartografia di riferimento (in Italian), http://ambiente.regione.emilia-romagna.it/geologia/temi/sismica/ speciale-terremoto/ sisma-2012-ordinanza-70-1311-2012-cartografia

Reimer, P.J., Bard, E., Bayliss, A., Beck, J.W., Blackwell, P.G., Bronk Ramsey, C., Buck, C.E., Cheng, H., Edwards, R.L., Friedrich, M., Grootes, P.M., Guilderson, T.P., Haflidason, H., Hajdas, I., Hatté, C., Heaton, T.J., Hogg, A.G., Hughen, K.A., Kaiser, K.F., Kromer, B., Manning, S.W., Niu, M., Reimer, R.W., Richards, D.A., Scott, E.M., Southon, J.R., Turney, C.S.M. and van der Plicht, J. (2013).1 IntCal13 and MARINE13 radiocarbon age calibration curves 0-50000 years calBP, Radiocarbon 55(4), doi: $10.2458 / \mathrm{azu}$ _js_rc.55.16947

Robertson, P.K. (2012). The James K. Mitchell Lecture: Interpretation of in-situ tests - some insights, Proc. 4th Int. Conf. on Geotechnical and Geophysical Site Characterization - ISC'4, Porto de Galinhas, Brazil 1: 3-24.

Rollins, K.M. and Hollenbaugh, J.E. (2015). Liquefaction induced negative skin friction from blast-induced liquefaction tests with auger-cast piles. Procs., 6th Intl. Conf. on Earthquake Geotechnical Engineering, Christchurch, New Zealand, New Zealand Geotechnical Society, 8 p.

Rollins, K.M. and Strand, S.R. (2006). Downdrag Forc- 
es due to Liquefaction Surrounding a Pile. Proc. 8th National Conference on Earthquake Engineering, Earthquake Engineering Research Institute, $10 \mathrm{p}$.

Rollins, K.M., Lane, J.D., Nicholson, P.G. and Rollins, R.E. (2004). Liquefaction hazard assessment using controlled blasting techniques, Proc. 11th International 93 Conference on Soil Dynamics and Earthquake Engineering, 2: 630 - 637.

Servizio Geologico Sismico e dei Suoli, Regione Emilia-Romagna (2016). Banche dati territoriali, a cura di Servizio Geologico Sismico e dei Suoli, Regione Emilia-Romagna.

Tokimatsu, K. and Seed, H.B. (1987). Evaluation of Settlements in Sands Due to Earthquake Shaking, J. of Geotechnical Engineering, ASCE, 113(8): 861-878.

Tsai, P., Lee, D., Kung, G.T. and Juang, C.H. (2009). Simplified DMT-based methods for evaluating liquefaction resistance of soils, Engineering Geology ,103: 13-22.

Vannucchi, G., Crespellani, T., Facciorusso J., Ghinelli, A., Madiai C., Puliti, A., and Renzi, S. (2012). Soil liquefaction phenomena observed in recent seismic events in Emilia-Romagna Region, Italy, Ingegneria Sisimica, N. 2-3, pp. 20-30, ISSN: 03931420.

Weltje, G.J. (2002). Quantitative analysis of detrital modes: statistically rigorous confidence regions in ternary diagrams and their use in sedimentary petrology, Earth-Sci. Rev. 57, 211 - 253.

Wentz, F.J., van Ballegooy, S., Rollins, K.M. Ashford S.A. and Olsen, M.J. (2015). Large Scale Testing of Shallow Ground Improvements using Blast-Induced Liquefaction, 6ICEGE - 6th International Conference on Earthquake Geotechnical Engineering 1-4 November 2015 Christchurch, New Zealand.

Yi, F.F. (2010). Procedure to Evaluate Liquefaction-Induced Settlement Based on Shear Wave Velocity, 9th U.S. National and 10th Canadian Conference on Earthquake Engineering 9USN/10CCEE, Toronto, Canada.

Zhang, G., Robertson, P.K. and Brachman, R.W.I. (2002). Estimating liquefaction-induced ground settlements from CPT for level ground. Canadian Geotechnical Journal, 39(5): 1168-1180.

\footnotetext{
${ }^{*}$ Corresponding author: Sara Amoroso, Istituto Nazionale di Geofisica e Vulcanologia, L’Aquila, Italy; email: sara.amoroso@ingv.it.

2017 by Istituto Nazionale di Geofisica e Vulcanologia.

All rights reserved
} 